Article

\title{
A Multi-Channel Algorithm for Mapping Volcanic Thermal Anomalies by Means of Sentinel-2 MSI and Landsat-8 OLI Data
}

\author{
Francesco Marchese ${ }^{1, *(\mathbb{D}}$, Nicola Genzano ${ }^{2}\left({ }^{\circ}\right.$, Marco Neri $^{3}{ }^{(0)}$, Alfredo Falconieri $^{1}{ }^{10}$, \\ Giuseppe Mazzeo ${ }^{1}$ (D) and Nicola Pergola ${ }^{1}$ (D) \\ 1 Consiglio Nazionale delle Ricerche-Istituto di Metodologie per 1 Analisi Ambientale, C. \\ da S. Loja, 85050 Tito Scalo (Pz), Italy; alfredo.falconieri@imaa.cnr.it (A.F.); \\ giuseppe.mazzeo@imaa.cnr.it (G.M.); nicola.pergola@imaa.cnr.it (N.P.) \\ 2 Scuola di Ingegneria, Università degli Studi della Basilicata, Via dell'Ateneo Lucano 10, 85100 Potenza, Italy; \\ nicola.genzano@unibas.it \\ 3 Istituto Nazionale di Geofisica e Vulcanologia, Sezione di Catania, Osservatorio Etneo, Piazza Roma 2, \\ 95125 Catania, Italy; marco.neri@ingv.it \\ * Correspondence: francesco.marchese@imaa.cnr.it; Tel.: +39-0971427225
}

Received: 11 October 2019; Accepted: 29 November 2019; Published: 3 December 2019

\begin{abstract}
The Multispectral Instrument (MSI) and the Operational Land Imager (OLI), respectively onboard Sentinel-2A/2B and Landsat 8 satellites, thanks to their features especially in terms of spatial/spectral resolution, represents two important instruments for investigating thermal volcanic activity from space. In this study, we used data from those sensors to test an original multichannel algorithm, which aims at mapping volcanic thermal anomalies at a global scale. The algorithm, named Normalized Hotspot Indices (NHI), combines two normalized indices, analyzing near infrared (NIR) and short wave infrared (SWIR) radiances, to identify hotspot pixels in daylight conditions. Results, achieved studying a number of active volcanoes located in different geographic areas and characterized by a different eruptive behavior, demonstrated the NHI capacity in mapping both subtle and more intense volcanic thermal anomalies despite some limitations (e.g., missed detections because of clouds/volcanic plumes). In addition, the study shows that the performance of NHI might be further increased using some additional spectral/spatial tests, in view of a possible usage of this algorithm within a known multi-temporal scheme of satellite data analysis. The low processing times and the straight forth exportability to data from other sensors make NHI, which is sensitive even to other high temperature sources, suited for mapping hot volcanic targets integrating information provided by current and well-established satellite-based volcanoes monitoring systems.
\end{abstract}

Keywords: volcanoes; thermal anomalies; Sentinel 2 MSI; Landsat-8 OLI

\section{Introduction}

Several studies have shown the important role of satellite observations in monitoring thermal volcanic activity, as a complement to field measurements or as a unique source of information, particularly in remote and inaccessible areas, where traditional surveillance systems often lack (e.g., [1-9]).

Sensors, such as Advanced Very High Resolution Radiometer (AVHRR) and Moderate Resolution Imaging Spectroradiometer (MODIS), providing data in medium infrared (MIR) and thermal infrared (TIR) bands, with a high temporal resolution (up to $6 \mathrm{~h}$ in the case of AVHRR), were widely used to monitor active volcanoes also operationally (e.g., [8-18]). Spinning Enhanced Visible Infra-Red Imager (SEVIRI), and other geostationary satellite sensors demonstrated a high potential in identifying eruption onset and in tracking short-lived eruptive events, thanks to the high frequency of observation (from 
15 to $10 \mathrm{~min}$ ) (e.g., [19-23]). These instruments were, however, less suited to map lava flows, and to retrieve accurate information about their features, because of low spatial resolution ( $1 \mathrm{~km}$ at nadir for MODIS; $3 \mathrm{~km}$ for SEVIRI). On the other hand, Thematic Mapper (TM) and Advanced Spaceborne Thermal Emission and Reflection Radiometer (ASTER), and image spectrometers, such as Hyperion, providing near infrared (NIR) and short wave infrared (SWIR) data at a medium-high spatial resolution (e.g., $30 \mathrm{~m}$ for ASTER) were better suited for this purpose (e.g., [4,5,24-28]). Recent studies exploited data from Operational Land Imager (OLI) and Multi-Spectral Instrument (MSI) sensors, respectively, onboard Landsat 8 and Sentinel 2A/2B satellites, which guarantee a global revisit time of $\sim 3$ days [29], for localizing active vents and quantifying volcanic thermal emissions (e.g., [28,30-36]). Some of these studies also showed advantages of integrating different satellite observations for better investigating volcanic and geothermal activity (e.g., [32-36]), even by means of land surface temperature estimations (e.g., [31,32]).

In this work, we present a single image multichannel algorithm for mapping volcanic thermal anomalies at a global scale, by means of infrared Sentinel 2 MSI and Landsat 8 OLI data. To test the algorithm, christened normalized hotspot indices (NHI), we investigated eight active volcanoes located in different geographic areas (Figure 1) and characterized by a different eruptive behavior. The proposed method, whose detections are assessed here by means of independent ground and satellite-based observations, uses two normalized indices to map volcanic thermal anomalies in daylight conditions analyzing SWIR and NIR radiances. Advantages and limitations in using these indices, which are different from other ones as the normalized thermal Index [16] (NTI) and thermal anomaly index [37] (TAI), respectively applied to MODIS and ASTER data, are analyzed and discussed in the next sections.
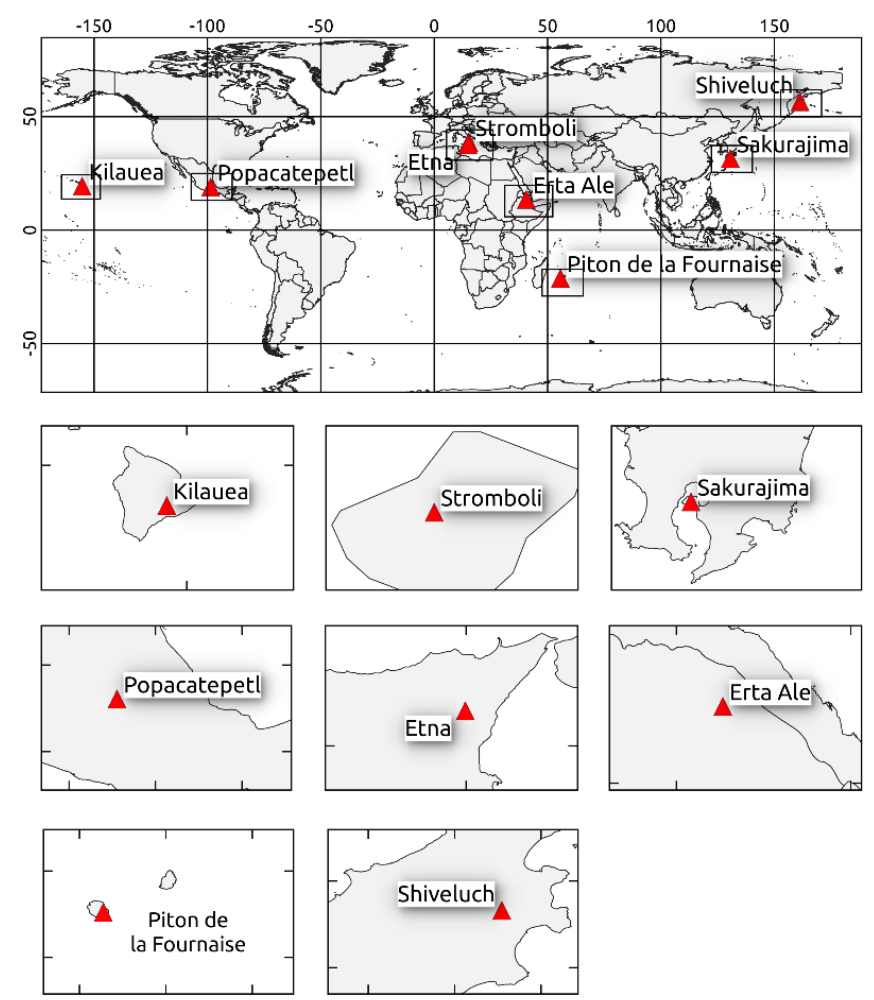

Figure 1. Geographic location of active volcanoes investigated in this work.

\section{Test Cases}

\subsection{Mt. Etna Eruptive Events of July 2018-February 2019}

Mt. Etna $\left(37.748^{\circ} \mathrm{N} ; 14.999^{\circ} \mathrm{E}\right)$ is the largest volcano in Europe and one of most active volcanoes in the world. Its eruptive activity frequently occurs from summit craters, although some intense flank eruptions took place in the last decades (e.g., [38]). 
In July 2018, after several months of low-level activity, an increase of Strombolian activity was recorded at Bocca Nuova (BN) (from BN-1 and BN-2 vents) and at North-East Crater (NEC). In late August, the E vent of the New South-East Crater (NSEC) complex emitted new lava flows. In the following three months, low-intensity Strombolian activity and intermittent ash emissions occurred from multiple vents at summit craters. In late November, a lava flow emerged from a small scoria cone inside the NSEC, continuing until the end of the month [39]. Between 4 and 24 December, Strombolian activity produced a fan-shaped lava field at NSEC [40]. During 24-27 December, a flank eruption occurred. In more detail, in the early morning of 24 December, a magmatic dyke intruded on the southeast flank of the volcano, leading to an intense seismic swarm culminating, two days after, with the strongest event (ML 4.8). This phenomenon caused extensive ground deformations along the southeastern flank of Mt. Etna, and superficial faulting having seriously damaged numerous roads and buildings [40]. At around 11:00 UTC, a main NNW-SSE eruptive fissure, $2 \mathrm{~km}$ in length, opened on the eastern flank of the volcano, at an altitude of 3100-2400 m above sea level (a.s.l.). Contemporary, another small fissure ( $70 \mathrm{~m})$ opened, between NEC and BN, at around $3000 \mathrm{~m}$ a.s.l., showing a weak Strombolian activity lasting a few tens of minutes only. The main fissure feeds some lava flows, extending up to about $1650 \mathrm{~m}$ a.s.l., inside the deserted Valle del Bove. A few hours before, and during the eruption, both BN and NEC produced a Strombolian activity, which was accompanied by the emission of dense ash columns. Since the beginning of January 2019, both NEC and BN vents emitted ash, while degassing and discontinuous explosive activity took place in February [41].

\subsection{Eruptive Events of Stromboli (Italy) Volcano of March-June 2019}

Stromboli $\left(38.789^{\circ} \mathrm{N} ; 15.213^{\circ} \mathrm{E}\right)$ is a stratovolcano located in the Aeolian Island (Italy). Strombolian eruptions and minor effusive activities generally characterize this volcano, although some important lava effusions occurred in recent years (e.g., [42-44]),

During March-April 2018, a number of explosions occurred from active vents located at the summit crater area. Eruptive activity continued through the following two months. In January 2019, magma remained high inside the conduits, and intermittent Strombolian explosions occurred from multiple vents. Afterwards, volcanic activity gradually decreased in intensity returning to normal levels. Small to moderate Strombolian explosions then occurred, at irregular intervals, from several vents through March 2019 [45]. Since 12 June, volcanic activity increased remaining at a moderate level until one day before the strong paroxysm of $3 \mathrm{July}$, when a gas bubble arrived at the surface, generating two lateral blasts causing the emissions of lava fragments at high temperature, and injecting a number of bush fires along the volcano slopes [46].

\subsection{Erta Ale (Africa) Eruptions of 2017}

Erta Ale $\left(13.6^{\circ} \mathrm{N} ; 40.67^{\circ} \mathrm{E}\right)$ is a shield volcano located in the Afar region of northeastern Ethiopia (Africa). It is among the few volcanoes in the world showing a persistent lava lake, which has been active during most of the past decades [47]. Two active craters (i.e., Northern and Southern ones), within the larger oval-shaped summit caldera, exhibit periodic lava fountaining causing lava-lake overflows [48].

Since late December 2016, an effusive eruption took place from active craters. On the morning of 16 January, 2017, the lake overflowed the $\mathrm{W}$ rim of the crater. Five days later, a new fissure opened on the SE volcano flank (about $4 \mathrm{~km}$ from the caldera) emitting lava [48,49]. Activity at the fissure vent strongly increased during mid-April/early June 2017, when pahoehoe lava flows moved in both NE and SW direction [48].

\subsection{Kilauea (Hawaii) Eruptive Activity of March 2018}

Kilauea $\left(19.421^{\circ} \mathrm{N} ; 155.287^{\circ} \mathrm{W}\right)$ is a shield volcano located in the Hawaiian Islands (United States), which has been continuously erupting since 1983 when open lava lakes, and flows from the summit caldera and East Rift Zone, occurred (e.g., [50,51]). Eruptive activity generally occurs from two vents, the Halema'uma'u crater (within the caldera), and the $\mathrm{Pu}^{\prime} \mathrm{u}$ ' ${ }^{\prime}{ }^{\prime} \bar{o}$ cone, which is located in the East Rift Zone at about $20 \mathrm{~km}$ from the summit (e.g., [52]). 
On 26 March, 2018, after a brief swarm of small earthquakes recorded in the upper East Rift Zone, and a long-period earthquake swarm, a small lava flow began erupting onto the $\mathrm{Pu}^{\prime} \mathrm{u}$ ' $\mathrm{O}^{\prime} \mathrm{o}$ crater floor. Eruptive activity followed a small increase in seismic events at $\mathrm{Pu}^{\prime} \mathrm{u}{ }^{\prime} \mathrm{O}^{\prime} \mathrm{o}$, and the opening of a first vent, forming a small pit about $35 \mathrm{~m}$ wide, five days before [52].

\subsection{Sakurajima (Japan) Eruptive Events of September-October 2018}

Sakurajima $\left(31.593^{\circ} \mathrm{N} ; 130.657^{\circ} \mathrm{E}\right)$ is an active volcano located in the Aira caldera, in southern Kyushu (Japan), which usually emits ash plumes and scatters blocks during eruptions from craters.

In July-December 2018, several ash emissions took place at the Minamidake crater. In September, when the maximum plume height was estimated around $2.3 \mathrm{~km}$ above the crater, incandescent blocks were emitted on volcano flanks. At the end of October, an observation flight revealed the occurrence of a fumarolic activity at the Showa crater. A dilute brown plume was observed at the Minamidake, which also showed an intermittent incandescence visible at the nighttime [53].

\subsection{Popocatepetl (Mexico) Eruptive Activity of March 2019}

Popocatépetl $\left(19.023^{\circ} \mathrm{N} ; 98.622^{\circ} \mathrm{W}\right)$ is a stratovolcano located in Central Mexico, which has been persistently active since 2005. Eruptive activity generally consists in the emission of gas/steam and ash plumes. Moreover, incandescent blocks are often scattered across the volcano flanks, and frequent growth of lava domes occur in the summit crater [54].

During March-August 2018, large emissions of volcanic $\mathrm{SO}_{2}$ occurred; steam/gas emissions were then observed in the following months. On 3 March, 2019, the National Center for Prevention of Disasters (CENAPRED) reported the emission of ash and water vapor. Volcanic explosions prompted local authorities to issue a yellow alert (middle level on a three-color scale), implementing a security perimeter in a 12-km radius of the crater [55]. On 14 March, a dense ash plume drifting NNE was emitted [56]. On 26 March, incandescent fragments ignited fires on volcano flanks. Three days later, an eruption occurred, generating an ash plume moving in the SE direction [56,57].

\subsection{Shiveluch (Kamchatka) Activity of March 2016-April 2019}

Shiveluch is one of the most active andesitic volcanoes of Kamchatka (Russia), which generally shows Vulcanian explosive eruptions and periods of dome growth [58].

During March 2016-April 2017, Kamchatka Volcanic Eruption Response Team (KVERT), performing daily video-visual and satellite monitoring of volcanoes in the Russian Federation [59], reported a lava-dome extrusion onto the $\mathrm{N}$ flank, strong fumarolic activity, dome incandescence, ash explosions, and hot avalanches. Thermal anomalies were then observed by satellite from August 2017 through January 2018 [60]. Between December 2018 and April 2019, both KVERT and Middle InfraRed Observation of Volcanic Activity (MIROVA), which monitors active volcanoes in near-real time by means of infrared MODIS data [61], revealed an increase in thermal volcanic activity. In early January and through April 2019, lava dome continued to grow extruding viscous lava blocks. Additionally, strong fumarolic emissions, gas-and-steam plumes containing ash were reported [62].

\subsection{Piton de la Fournaise (Reunion Islands) Eruptions of April 2018-June 2019}

Piton de la Fournaise is a basaltic shield volcano located in the Réunion Island (Indian Ocean), whose eruptive activity generally consist of lava fountains and effusive eruptions producing large lava flows (e.g., [63]). In the evening of 27 April, 2018 a seismic swarm accompanied by rapid deformation occurred, indicating the magma migration towards the surface. A few hours later, a new flank eruption started from fissures located at Rivals crater and SW flank of the Dolomieu crater. Eruptive activity continued through May, when lava flows were generally confined to tubes, and a small area of incandescence affected the main crater [64]. In 2019, two important effusive events occurred. The first one, lasting from 18 February-10 March, 2019, was associated with the opening of multiple fissures on the E flank of the Dolomieu crater. The second one began on 11 June at the SSE outer slope of Dolomieu crater, and lasted about $48 \mathrm{~h} \mathrm{[65].}$ 


\section{Data}

\subsection{Sentinel-2 MSI Data}

The Sentinel-2 mission was established within the European Space Agency (ESA) Copernicus program to perform multispectral high spatial resolution optical observations of land surfaces, inland and coastal waters (e.g., [66]). The mission is a constellation of two polar satellites (i.e., Sentinel-2A/2B), placed in the same sun-synchronous orbit and phased at $180^{\circ}$ to each other, orbiting the Earth at $786 \mathrm{~km}$ altitude [67]. The image swath width is about $290 \mathrm{~km}$, which is larger than Landsat [68]. The Sentinel-2 constellation guarantees a revisit time of 5 days at the equator in cloud-free conditions, increasing up to 3-5 days at mid-latitudes [66]. Sentinel-2 satellites are equipped with the MSI instrument, which is a state of the art push-broom imager, measuring the solar radiance reflected from the Earth in 13 spectral bands from the visible (VIS) to SWIR region (i.e., 443-2190 nm), with a spatial resolution of 10-60 m (see Table 1) [67,68].

Table 1. Spectral/spatial features of the Multi-Spectral Instrument (MSI) onboard Sentinel-2A/2B satellites.

\begin{tabular}{cccc}
\hline MSI Spectral Channel & Central Wavelength $(\mathbf{n m})$ & Bandwidth $(\mathbf{n m})$ & Spatial Resolution $(\mathbf{m})$ \\
\hline 1 & 443 & 20 & 60 \\
2 & 490 & 65 & 10 \\
3 & 560 & 35 & 10 \\
4 & 665 & 30 & 10 \\
5 & 705 & 15 & 20 \\
6 & 740 & 15 & 20 \\
7 & 783 & 20 & 20 \\
8 & 842 & 115 & 10 \\
$8 \mathrm{~A}$ & 865 & 20 & 20 \\
9 & 945 & 20 & 60 \\
10 & 1375 & 30 & 60 \\
11 & 1610 & 90 & 20 \\
12 & 2190 & 180 & 20 \\
\hline
\end{tabular}

Sentinel-2 data, made available to users, include the Level-1C and Level-2A products distributed through the ESA Open Access Hub [69]. The Sentinel-2 L1C product is a calibrated top-of-atmosphere (TOA) reflectance product composed of $100 \times 100 \mathrm{~km}^{2}$ tiles in the Universal Transverse Mercator/World Geodetic System 1984 (UTM/WGS84) projection. The product, containing parameters to transform reflectance into radiances, is resampled with a constant ground sampling distance, based on native resolution of the MSI spectral bands [70,71]. The Level 2A product is a bottom-of-atmosphere (BOA) reflectance product, which is in the same projection of the associated Level $1 \mathrm{C}$.

\subsection{Landsat 8 OLI Data}

Since 1972, the joint National Aeronautics and Space Administration (NASA)/U.S. Geological Survey (USGS) Landsat series have continuously acquired imagery of the Earth's land surface [72]. The Landsat 8 satellite, which was launched in 2013, orbits the Earth in a sun-synchronous, near-polar orbit at an altitude of $705 \mathrm{~km}$. The revisit time is 16-days and the image swath is about $185 \mathrm{~km}$. Thermal Infrared Sensor (TIRS) and OLI are the two instruments onboard this satellite.

TIRS is a two-band thermal sensor operating from 10.6-12.5 $\mu \mathrm{m}$. OLI is a pushbroom sensor, having a 12-bit radiometric resolution, providing data in nine spectral channels, with a spatial resolution from $15 \mathrm{~m}$ (panchromatic) to $30 \mathrm{~m}$ in the visible/infrared bands (see Table 2) (e.g., [73]).

In this work, we used the Landsat 8 OLI Level 1 data products, made freely available online by USGS, for running the NHI algorithm. We converted digital numbers (DNs) to TOA spectral radiance by using the rescaling coefficients found in the metadata (MTL) file. 
Table 2. Spectral/spatial features of the Operational Land Imager (OLI) instrument onboard Landsat 8 satellite.

\begin{tabular}{cccc}
\hline OLI Spectral Channel & Central Wavelength $(\mathbf{n m})$ & Bandwidth $(\mathbf{n m})$ & Spatial Resolution $(\mathbf{m})$ \\
\hline 1 & 443 & 16 & 30 \\
2 & 482.6 & 60 & 30 \\
3 & 561.3 & 57 & 30 \\
4 & 654.6 & 37 & 30 \\
5 & 864.6 & 28 & 30 \\
6 & 1609.1 & 85 & 30 \\
7 & 2201.7 & 187 & 30 \\
8 & 590 & 172 & 15 \\
9 & 1373 & 20 & 30 \\
\hline
\end{tabular}

\section{Methods}

\subsection{Background}

Several algorithms have been, up to now, proposed to detect and map thermal anomalies (e.g., fires; lava flows) using high-spatial resolution satellite data. Among the most recent ones, HOTMAP [30] uses two binary parameters, analyzing the TOA reflectance measured in bands $5(0.87 \mu \mathrm{m}), 6(1.61 \mu \mathrm{m})$, and $7(2.2 \mu \mathrm{m})$ of the OLI sensor, to detect hotspots. The algorithm was compared to Autonomous Sciencecraft Experiment (ASE) developed for Hyperion [28] and to a contextual method originally designed for ASTER [74], showing better performance in detecting thermal anomalies at a global scale [30]. Other authors proposed an enhancement of HOTMAP, coupling a contextual analysis to the spectral ratios of SWIR signal, for better investigating volcanic thermal anomalies by means of Sentinel 2 MSI data [75]. The method runs operationally within the Monitoring Unrest from Space (MOUNT) platform, which monitors several active volcanoes in near-real time through a multi-sensor observing system [34]. These techniques, such as other novels algorithms of fire detection (e.g., those integrating a multi-temporal scheme of satellite data analysis [76] or using a three-band index analyzing both NIR and SWIR radiances [77]), confirmed the important role of high-spatial resolution satellite observations in supporting volcanic hazard and fire management activities. In this context, the algorithm presented in this work, using a simple detection scheme, which may be easily applied to data from different sensors, aims at performing a quick and efficient mapping of volcanic thermal anomalies in daylight conditions, regardless of geographic areas and periods of the year.

\subsection{NHI Algorithm}

Hot targets (e.g., lava flows) are particularly radiant in the SWIR spectral region (e.g., [5]). Moreover, higher temperature surfaces emit strongly at shorter rather than longer SWIR wavelengths (e.g., [78]). Hence, sensors having channels in the SWIR bands can be used to identify and map volcanic thermal anomalies (e.g., [78,79]). On the other hand, during daytime the reflected solar radiation represents a major issue (e.g., [80,81]). The NHI algorithm takes into account that mentioned above using two normalized indices to detect and map volcanic hotspots:

$$
\begin{gathered}
N I_{\text {SWIR }}=\frac{L_{2.2}-L_{1.6}}{L_{2.2}+L_{1.6}} \\
\text { NHI }_{\text {SWNIR }}=\frac{L_{1.6}-L_{0.8}}{L_{1.6}+L_{0.8}}
\end{gathered}
$$

where, $L_{2.2}, L_{1.6}$, and $L_{0.8}$ are the TOA radiances $\left[\mathrm{W} \mathrm{m}^{-2} \mathrm{sr}^{-1} \mu \mathrm{m}^{-1}\right.$ ] measured, for each pixel of the analyzed scene, at around $2.2 \mu \mathrm{m}, 1.6 \mu \mathrm{m}$ (SWIR), and $0.8 \mu \mathrm{m}$ (NIR) wavelengths, in the relative MSI/OLI spectral bands. The index in Equation (1), analyzing SWIR radiances, takes into account that previously shown by other authors using airborne data [82]. The index in Equation (2), which uses the same 
spectral bands of the Normalized Burnt Ratio (NBR) highlighting burn surfaces [83], should enable a more efficient identification of high-temperature surfaces. We assessed the NHI indices behavior by analyzing several Sentinel 2 MSI and Landsat 8 OLI scenes. An example is shown in Figure 2a, displaying the Red; Green; Blue (RGB) product from Sentinel 2 MSI data of 26 December, 2018 at 09:44 UTC, covering the Mt. Etna area.

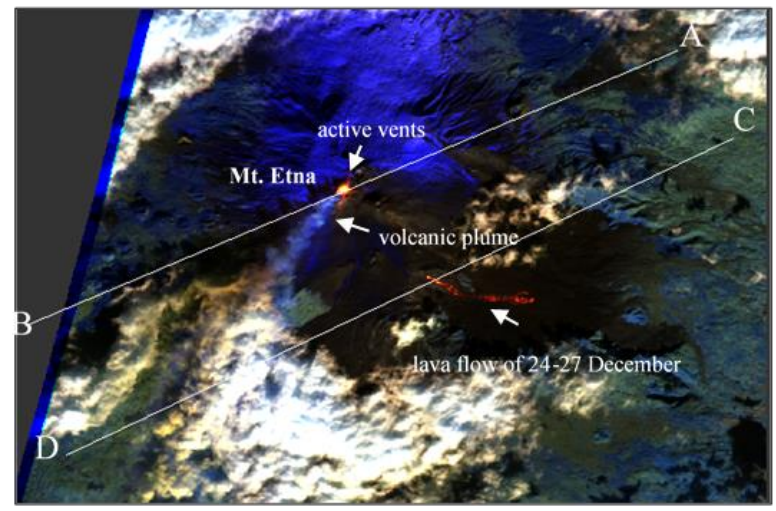

(a)
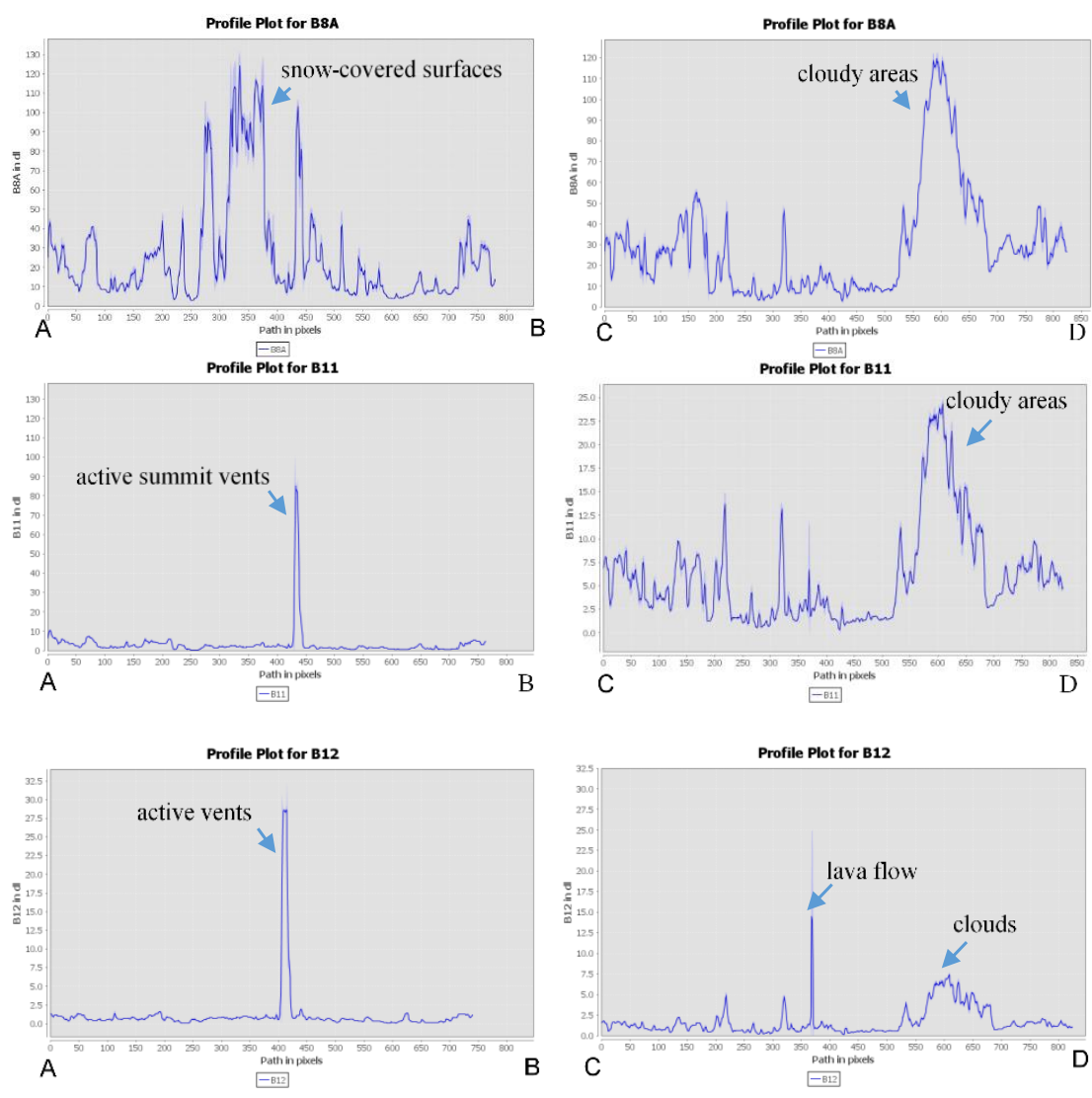

(b)

Figure 2. (a) The Red; Green; Blue (RGB) product from Sentinel 2 MSI data of 28 December, 2018 at 09:44 UTC, covering Mt Etna area. The product was generated after converting top-of-atmosphere (TOA) reflectance, measured in band 12 (Red), band 11 (Green), and band 8A (Blue), to radiance by means of the Sentinel Application Platform (SNAP) tool from the European Space Agency (ESA); (b) Radiance changes recorded along the A-B (left panels) and $\mathrm{C}-\mathrm{D}$ (right panels) transect regions intersecting the crater area and Valle del Bove, respectively. 
The false color composite imagery, which was generated by combining bands 12(Red), 11(Green), and $8 \mathrm{~A}$ (Blue) of MSI after converting TOA reflectance to radiance by means of the Sentinel Application Platform (SNAP) tool from ESA, emphasized hot features, clouds, background surfaces, and a volcanic plume, dispersing in the SW direction, in different colors. In particular, hotspot pixels, appearing yellow/red colored, could be well discriminated from other features as clouds (pixels from gray to white). Indeed, radiance changes recorded along the transect regions of Figure 2a showed that clouds and snow-covered areas leaded to the peak of $L_{0.8}$ radiance, highest $L_{1.6}$ values occurred over clouds (because of reflected solar radiance) and active summit vents (due to emitted radiance), while $L_{2.2}$ radiance increased over both crater area and the SE volcano flank (see Figure $2 b$ ).

By analyzing the behavior of NHI indices along the same transect regions of Figure $2 \mathrm{a}$, we found that volcanic thermal anomalies could be well distinguished from other features as evident in Figure 3, showing the NHI imagery (top panels) and the spatial changes of NHI indices (middle-bottom panels).
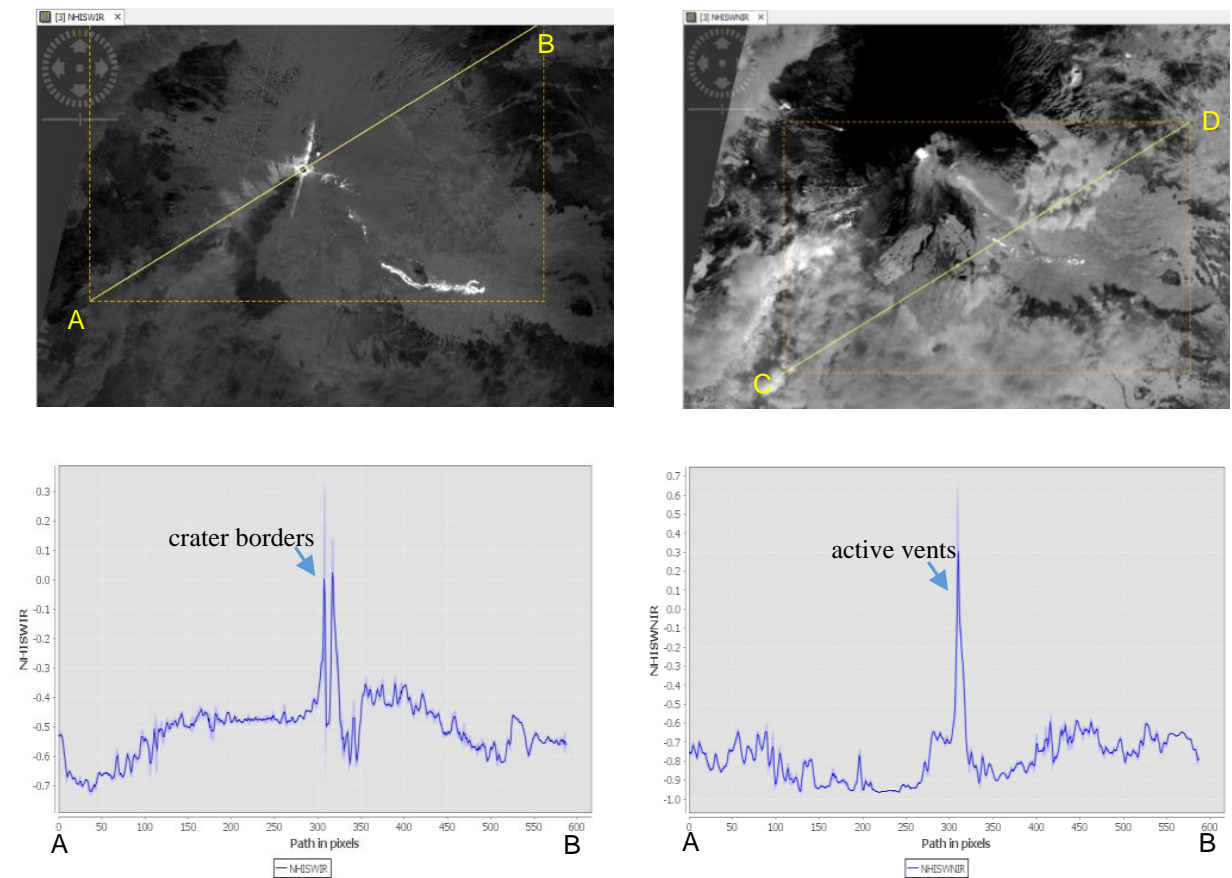

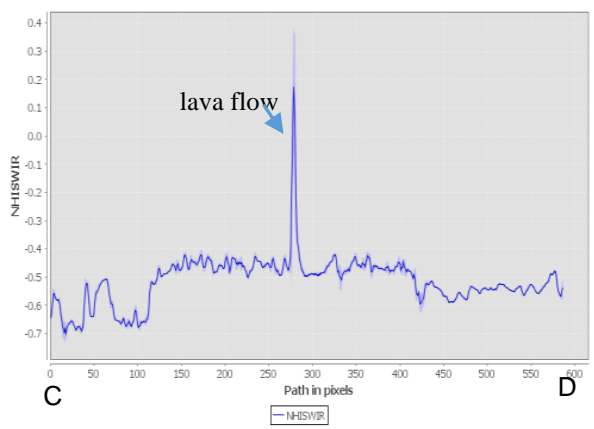

(a)

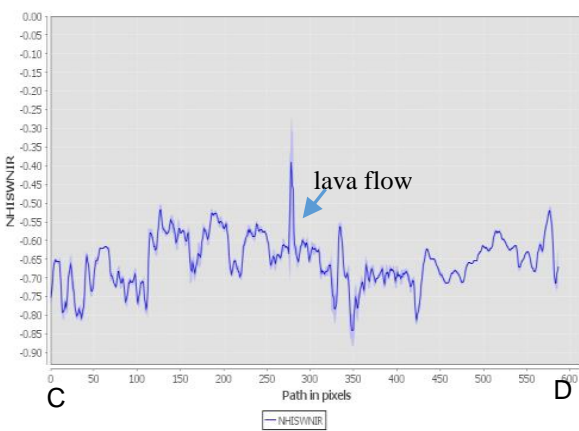

(b)

Figure 3. Normalized Hotspot Indices (NHI) imagery from Sentinel-2A MSI data of 28 December, 2018 (on the top) and changes of two NHI indices retrieved along the same A-B and C-D transect regions of Figure 2a (middle-bottom panels); (a) $\mathrm{NHI}_{S W I R}$; (b) $\mathrm{NHI}_{S W N I R}$.

Looking at the plots, it can be noted as while the index in Equation (1) increased up to positive values at crater borders and on SE flank of the volcano (Figure 3a), where lava effusion was significantly less intense than previous days, the index in Equation (2) became positive mainly over summit active vents 
(Figure 3b). This analysis, such as similar investigations, revealed a sort of complementary behavior of the two indices, suggesting to us to analyze pixels with values of $N H I_{S W I R}>0$ or $N H I_{S W N I R}>0$ to identify and map volcanic thermal anomalies in the areas of Figure 1. The index in Equation (1) seems to be, in fact, more sensitive to low-medium intensity hotspots but less capable of mapping strong thermal anomalies than the index in Equation (2).

\section{Results}

In this section, we show results achieved analyzing hundreds of Sentinel 2 MSI and Landsat 8 OLI scenes by means of NHI algorithm; investigations were extended also to some neighbor non-volcanic areas of Figure 1, for better analyzing factors affecting NHI performance.

NHI maps shown here display hotspot pixels in two different colors. In detail, we depicted hotspot pixels in red $\left(N H I_{S W N I R}>0\right)$ and yellow $\left(N H I_{S W I R}>0\right)$, retrieving qualitative information about areas where thermal emissions were strong or less intense (see previous section).

\subsection{Mt. Etna Eruptive Events of July 2018-February 2019}

To assess the NHI potential in mapping thermal anomalies at Mt. Etna (Sicily, Italy) area, we processed all the Sentinel-2 MSI scenes acquired during July 2018-February 2019 at around 10:00 UTC. Figure 4 displays a number of NHI maps, where we marked active vents, including the enlarged region of interest (ROI) reported at the top-right side of the figure.
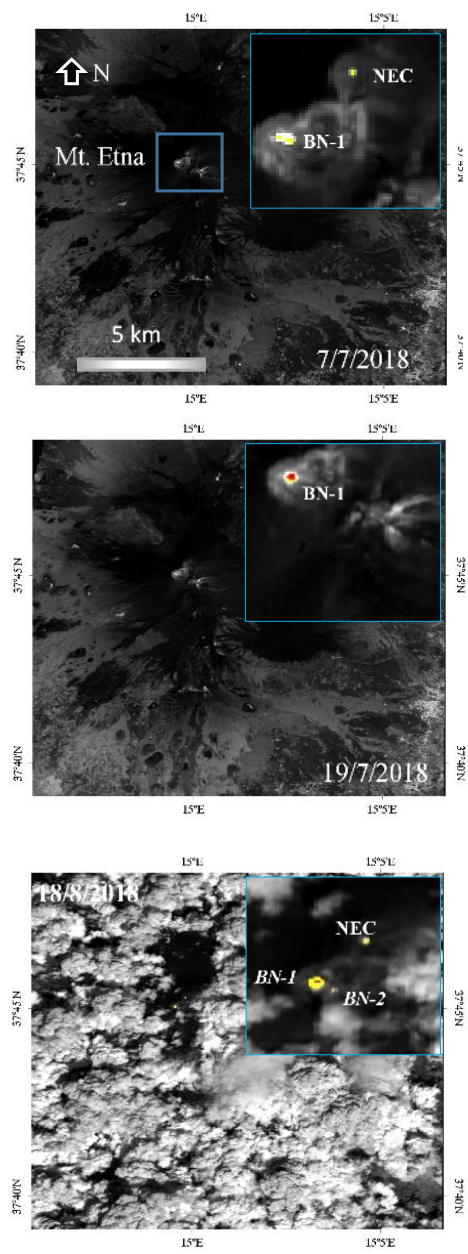
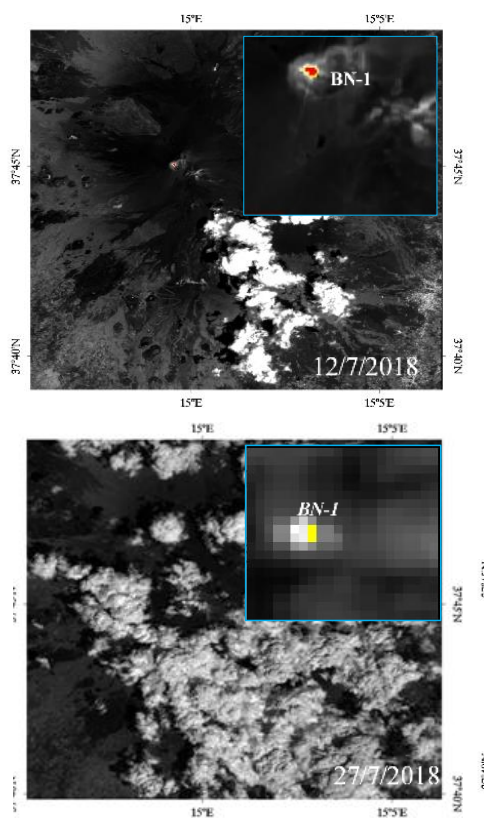

1SE

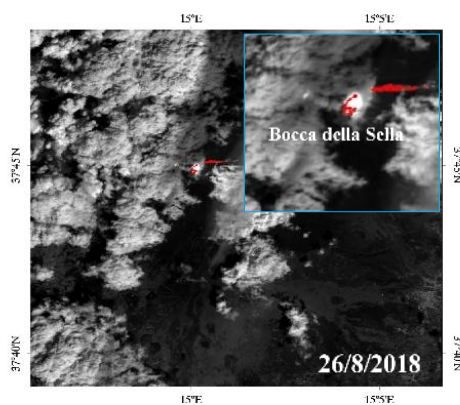

15.
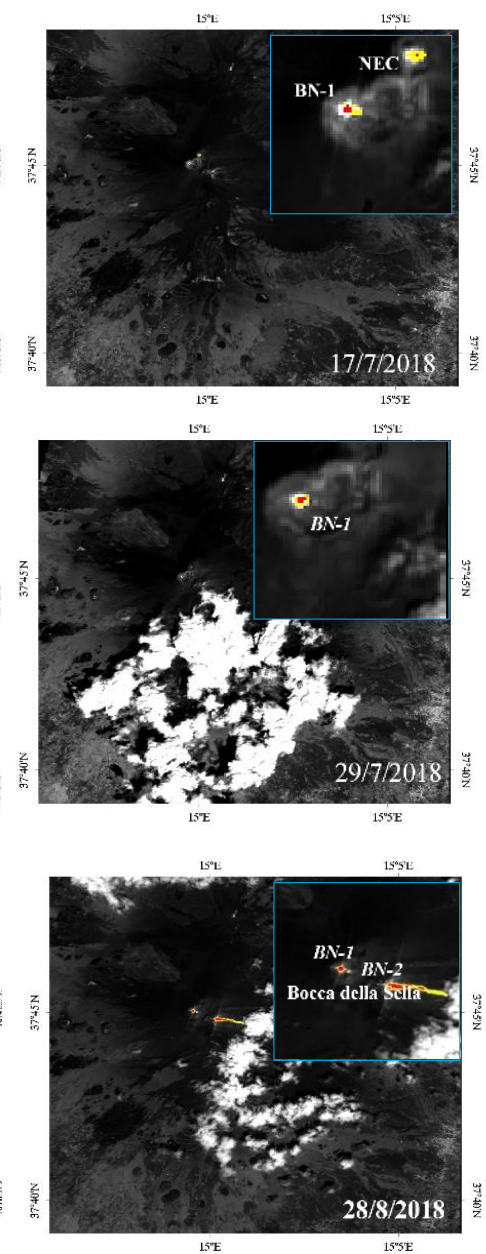

Figure 4. Cont. 

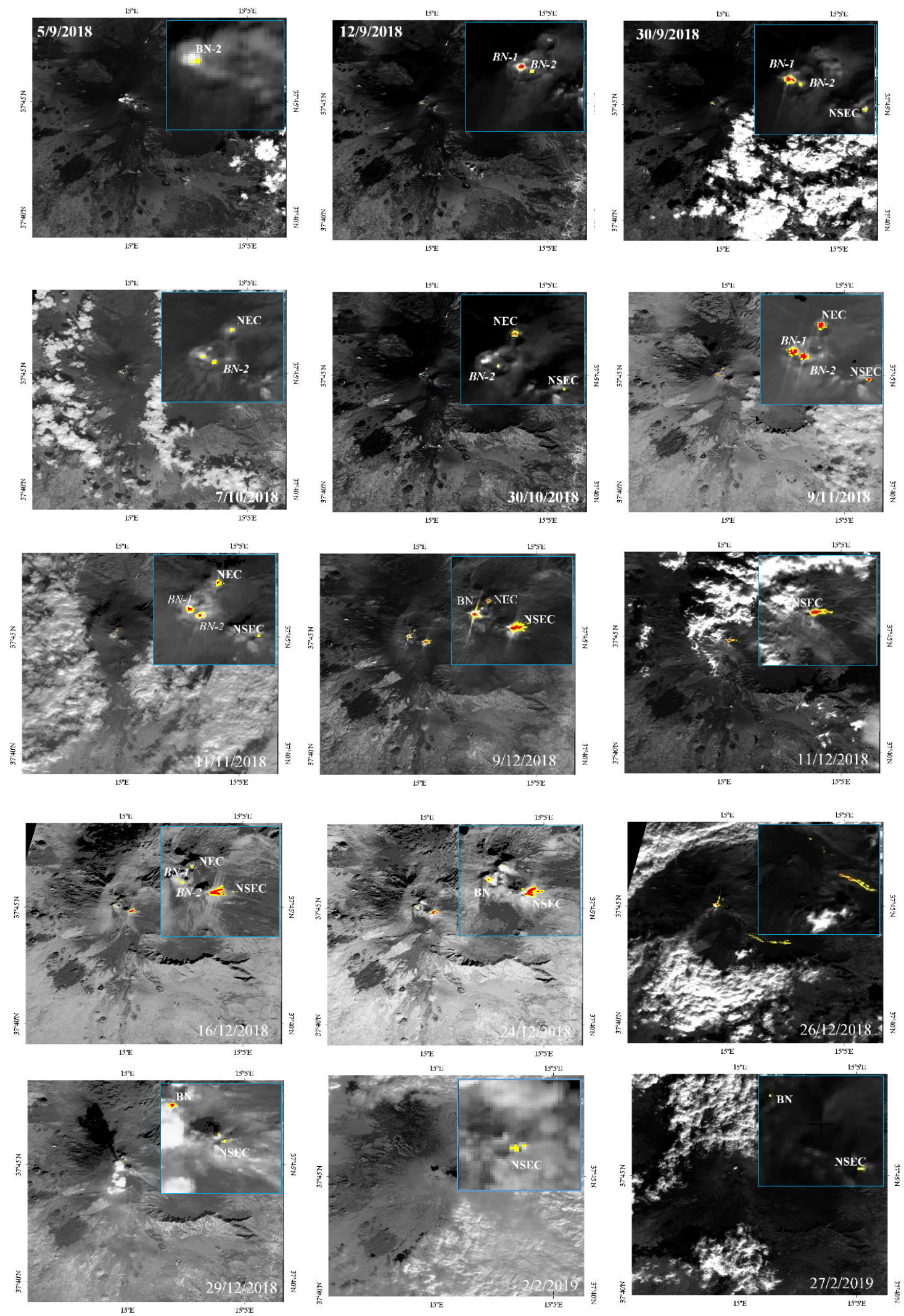

Figure 4. NHI maps (in Lat/Long WGS84 projection) from Sentinel-2 MSI scenes of July 2018-February 2019 covering Mt. Etna area (in background the Band 12 imagery). In yellow, pixels having values of $\mathrm{NHI}_{\text {SWIR }}(x, y)>0$, in red those with values of $\operatorname{NHI}_{\text {SWNIR }}(x, y)>0$. 
During July-August 2018, NHI flagged several hotspot pixels at the crater area, and more in particular at $\mathrm{BN}-1$ and $\mathrm{BN}-2$, which were located on the bottom of Bocca Nuova (BN) crater, and at NEC, because of ongoing Strombolian activity. In addition, NHI correctly identified the lava effusion occurring at the end of August from the Bocca della Sella vent, which is located between the old and the New South-East Crater (NSEC) (see panels of 26-28 August). NHI maps of September-October indicated that both BN-1 and BN-2 were active, such as the NEC. Additionally, they showed the presence of a thermal anomaly at NSEC (see panel of 30 October), which was possibly associated to the fumarolic activity. Since the second week of November, the number of hotspot pixels (mostly those depicted in red) increased, revealing the presence of a more intense and extended thermal anomaly. In mid-December, NHI maps showed the occurrence of a thermal activity at NEC, BN, and NSEC, while those of 24-26 December marked the lava effusion occurring from a new fissure which opened in the upper part of Valle del Bove. Since the end of December, the number of hotspot pixels significantly decreased, revealing the intensity reduction of thermal volcanic activity. In particular, NHI flagged some hot spots pixels mainly at BN and NSEC (e.g., see panels of 2 and 27 February 2019), where a degassing activity was independently reported (see Section 2.1).

NHI detections described above were in good agreement with independent ground-based observations. On the other hand, although NHI provided reliable information about active vents, the manual inspection of satellite imagery (both visible and infrared ones) and the comparison with the RGB product (generated as Figure 2) revealed that in a few maps some background pixels were erroneously flagged as hotspots (e.g., as for panel of 26 December 2018). Pros and cons of the here proposed algorithm, emphasized also by results achieved using NHI for mapping thermal anomalies in the other volcanic areas of Figure 1, are analyzed and discussed in detail in Section 6.

\subsection{Activity of Stromboli Vlcano of March-June 2019}

Figure 5 displays the NHI maps generated from Sentinel-2 MSI data of March/June 2019 covering the Stromboli (Italy) volcano.

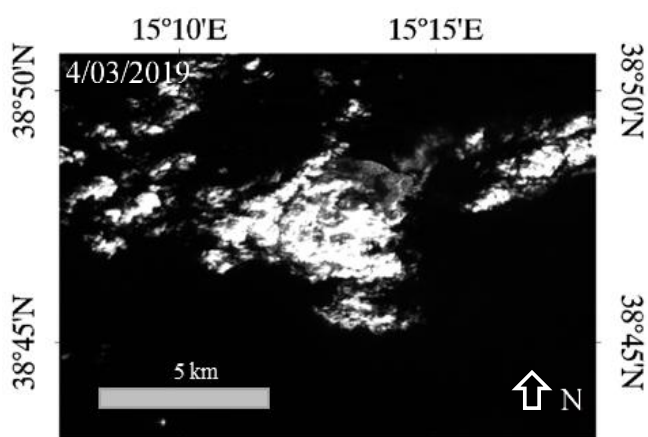

$15^{\circ} 10^{\prime} \mathrm{E}$

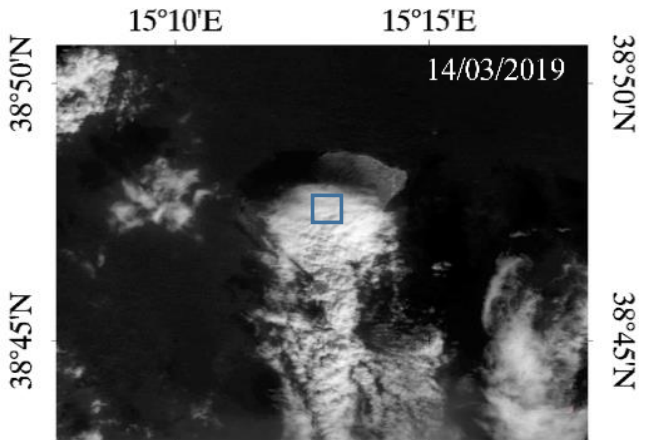

$15^{\circ} 10^{\prime} \mathrm{E}$ $15^{\circ} 15^{\prime} \mathrm{E}$

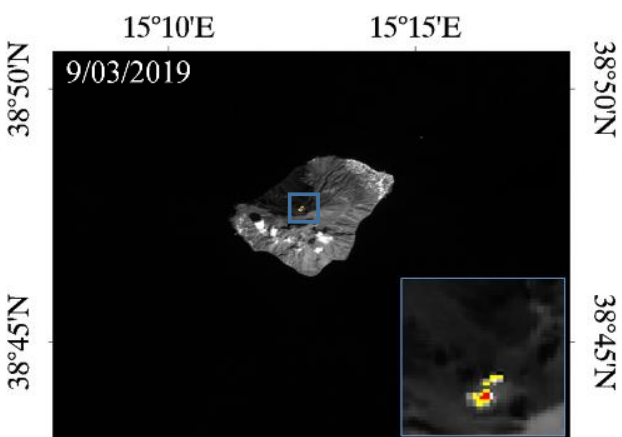

$15^{\circ} 10^{\prime} \mathrm{E}$

$15^{\circ} 15^{\prime} \mathrm{E}$

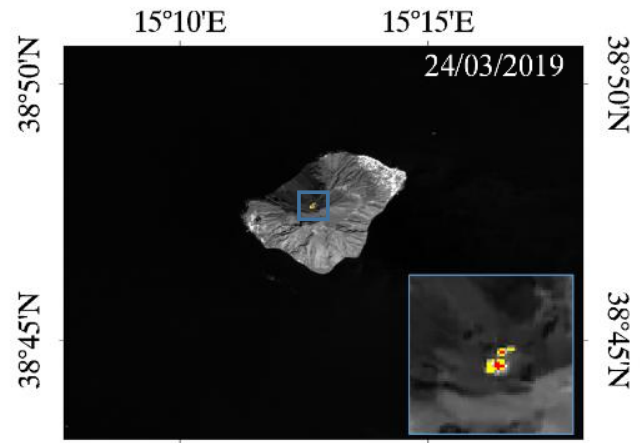

$15^{\circ} 10^{\prime} \mathrm{E}$

Figure 5. Cont. 

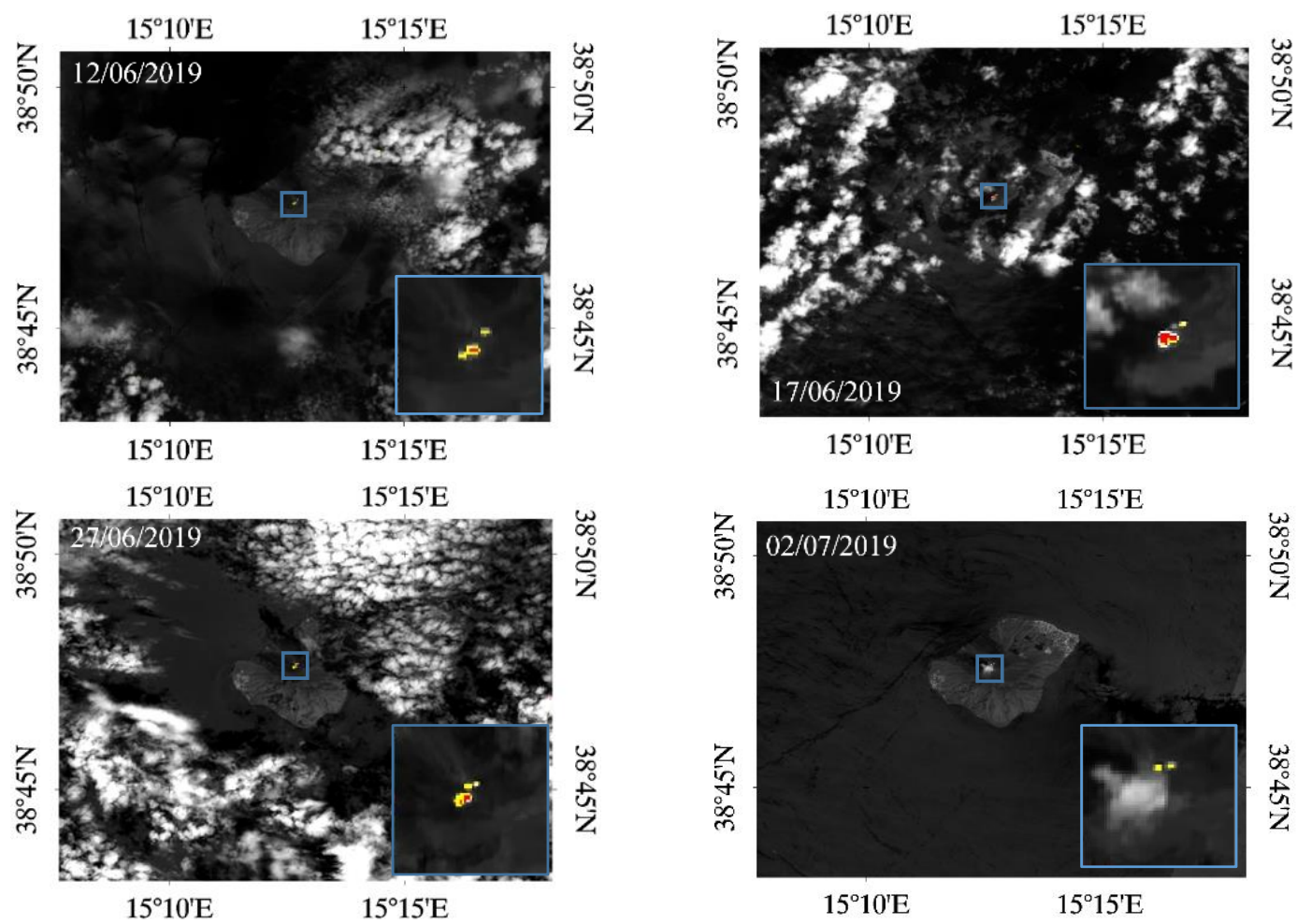

Figure 5. NHI maps from Sentinel-2 MSI data of March and June 2019 covering Stromboli volcano. Yellow/red pixels indicate hotspot pixels flagged by NHI.

As can be seen from the figure, NHI detected a thermal anomaly at the crater area since 9 March, when the cloud coverage was less significant. The thermal anomaly, including two clusters of hotspot pixels (see region marked in blue magnified at the bottom right side of the figure), appeared more extended and intense on the SW side of the summit crater area (e.g., see panel of 24 March), where presumably higher was the number of active vents. By analyzing the Sentinel-2 MSI scenes of June, we observed a general increase of thermal volcanic activity starting from the second week of the month (e.g., see panel of 17 June). Strombolian explosions, as well as a degassing activity occurring from multiple vents within the crater, corroborated information retrieved by satellite.

It is interesting to note that NHI identified a volcanic thermal anomaly, at the crater area, even one day before the strong paroxysm of 3 July (see Figure 5). This powerful event was the largest occurring since the 1930s, and caused the death of a hiker [46]. However, the detected thermal anomaly, which was partially masked by clouds (see panel of 2 July), did not represent a thermal precursor of that eruption. Indeed, the moderate Strombolian activity occurring since mid-June and continuing through 2 July [84] generated the thermal anomaly identified and mapped by NHI.

\subsection{Erta-Ale Euptions of 2017}

Figure 6 displays a number of NHI maps from Sentinel-2 MSI data of January-March 2017, showing changes in thermal volcanic activity occurring at Erta Ale (Ethiopia, Africa) during the period of interest. In more detail, the figure shows that while hotspot pixels (red/yellow ones) flagged in middle-January were mostly related to the lava lake within the caldera (see region magnified at the top right side of the figure), those identified by NHI since the end of the month were ascribable to a documented lava effusion (see Section 2.3). 

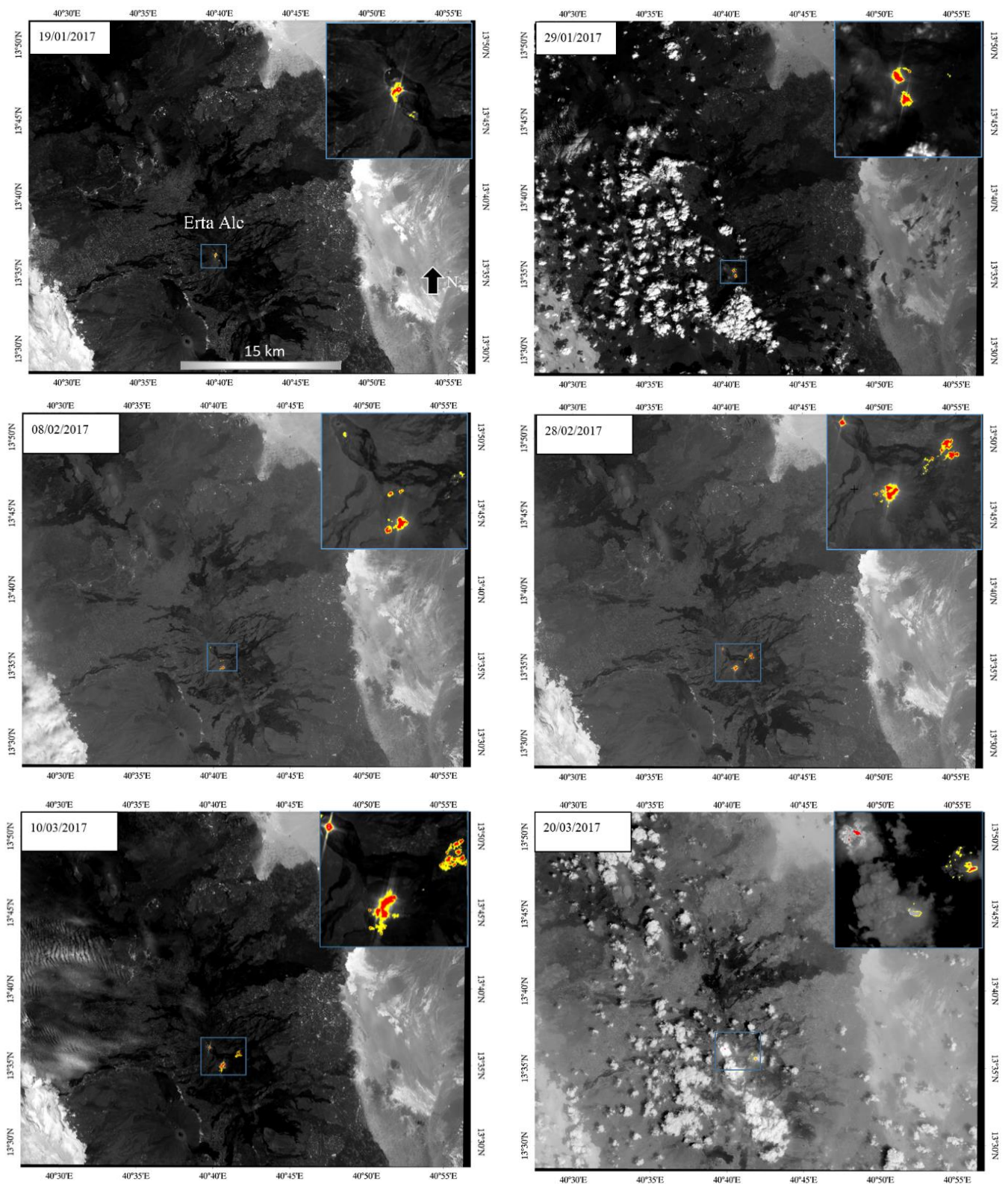

Figure 6. NHI maps from Sentinel-2 MSI data acquired in March 2017 covering the area of Erta Ale volcano. Yellow/red pixels indicate hotspot pixels flagged by NHI.

In February, other clusters of hotspot pixels were recognizable, revealing since the end of same month a general increase of effusive activity. Afterwards, meteorological clouds mostly obscured the ROI, leading to the underestimation of volcanic thermal anomaly (e.g., see panel of $20 \mathrm{March}$ ).

We assessed the NHI potential in mapping thermal anomalies at Erta Ale also in other periods of the year. As an example, Figure 7 displays two NHI maps of December 2017 highlighting the presence of a thermal anomaly at the caldera, where the lava lake was persistent (Figure 7a), as well as East of analyzed satellite scenes (e.g., see region marked in green at the top-right side of Figure $7 \mathrm{~b}$ ).

Therefore, based on information provided by NHI, the lava flow emitted on SE flank of the volcano since January 2017 moved even in the NE direction fitting with that reported by volcanological bulletins (see Section 2.3). 


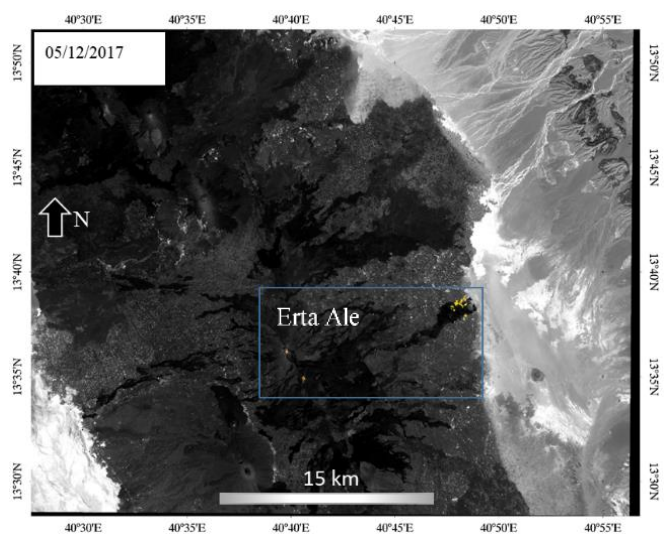

(a)

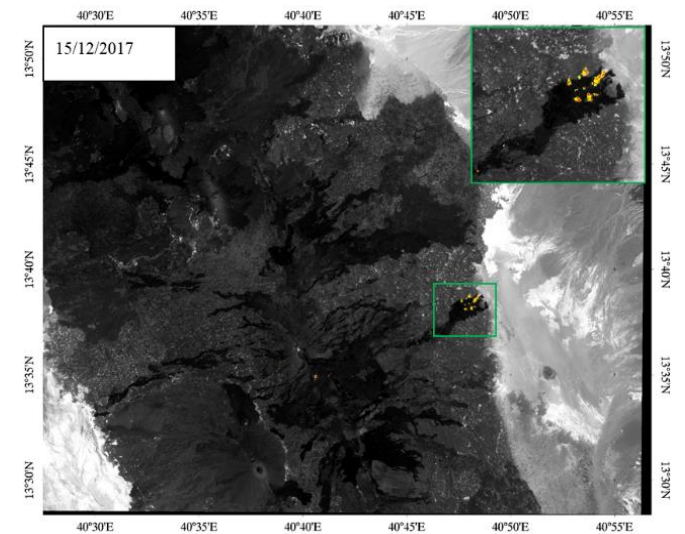

(b)

Figure 7. NHI maps from two Sentinel-2 MSI data of December 2017 covering the Erta Ale volcanic area; (a) 5 December, 2017; (b) 15 December, 2017.

\subsection{Kilauea Eruptive Activity of March 2018}

In Figure 8, we show two NHI maps generated from Sentinel-2 MSI data of March 2018, including the area of Kilauea (Hawaii Islands) volcano. Specifically, Figure 8a displays the NHI map of 4 March showing the presence of a thermal anomaly at Halema 'uma' $u$ crater (see yellow pixels within the region marked in green), which was partially identified by satellite due to a thick cloud coverage and a volcanic plume dispersing in the SW direction.

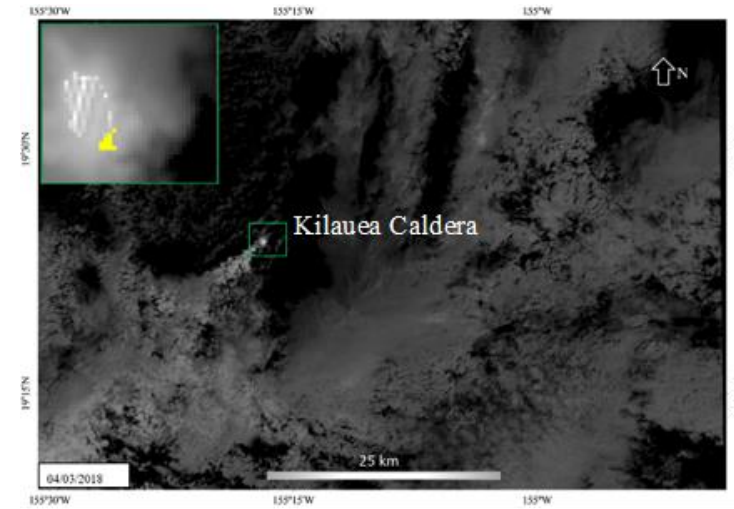

(a)

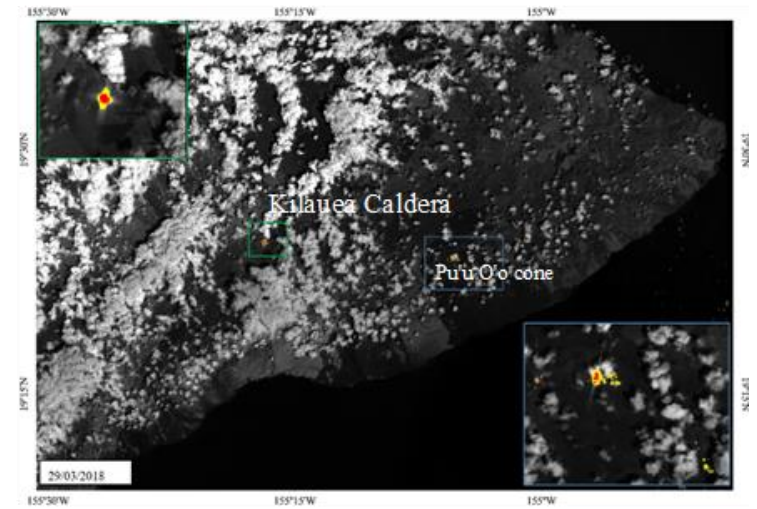

(b)

Figure 8. NHI maps from Sentinel-2 MSI data covering part of the Hawaii Islands and including the Kilauea volcano; (a) 4 March, 2018; (b) 29 March, 2018.

Map of Figure 8b, which was generated from satellite data of 29 March, shows that NHI identified the volcanic thermal anomaly in a more efficient way when the aforementioned features did not affect the crater area. In addition, the figure shows that NHI flagged several hotspot pixels at the East Rift Zone (see red/yellow pixels within the blue box magnified at the bottom right side of the figure), which were ascribable to the eruptive activity began in March 2018 at the Pu'u O'o cone (see Section 2.4).

\subsection{Sakurajima Thermal Activity of October 2018}

Figure 9 shows a sequence of NHI maps, generated from Sentinel 2 MSI data of October 2018, covering the area of Sakurajima volcano. Maps show that since the third week of October (i.e., when the cloud coverage was less significant), NHI flagged the occurrence of a moderate thermal activity at the Minamidake crater (see yellow pixels within the region marked in blue, magnified at the top 
right side of the figure). NHI did not detect, however, any hotspot pixel at the Showa crater where independent observations reported the occurrence of a fumarolic activity (see Section 2.5). The manual inspection of satellite imagery, and the comparison with the qualitative RGB product, performed as for Mt. Etna (see Section 5.1), corroborated that indicated by NHI. Thus, it is realistic to suppose that the fumarolic activity was not in progress at the time of analyzed satellite observations or it was particularly weak and then difficult to be identified by satellite.
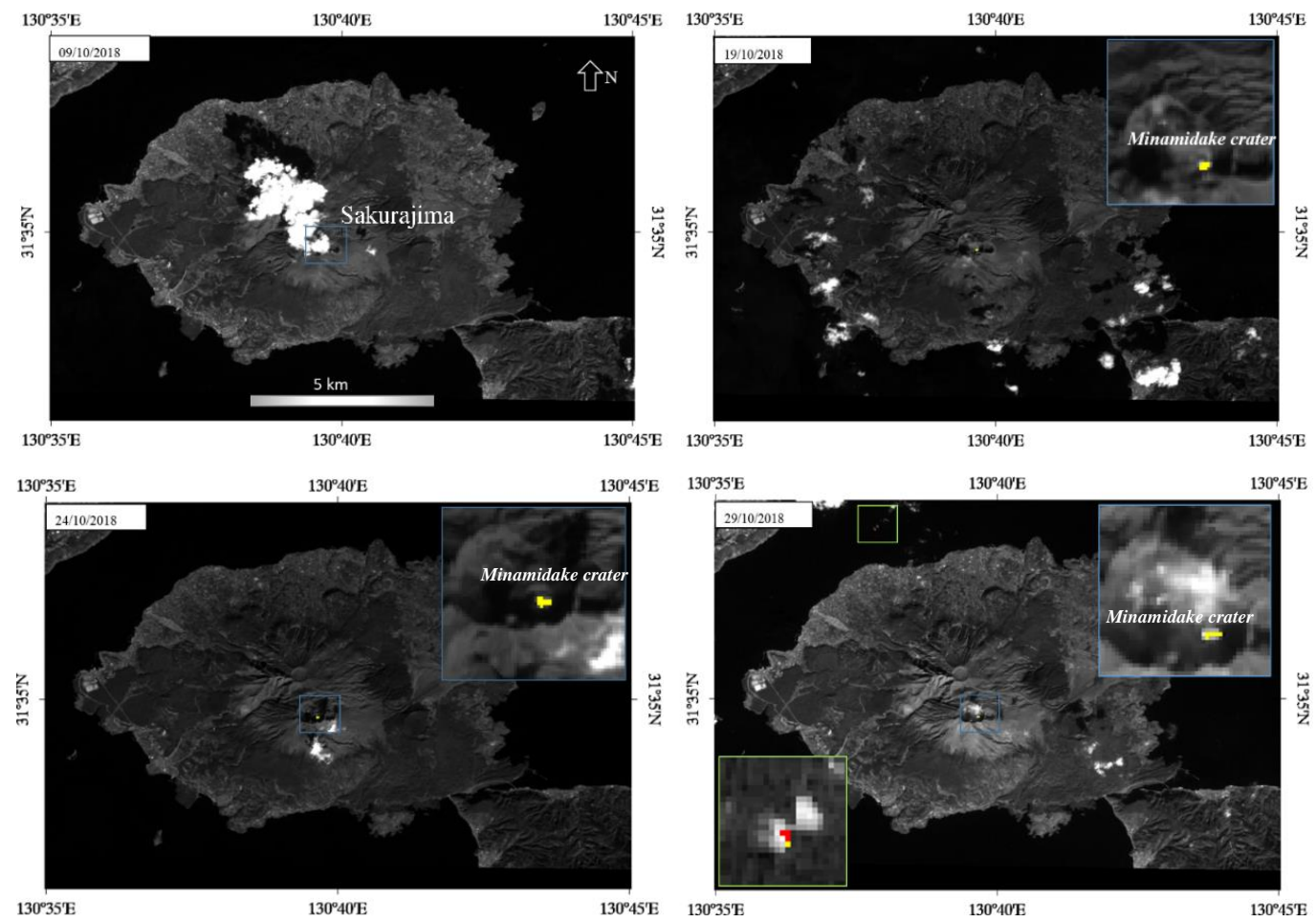

Figure 9. NHI maps from Sentinel-2 MSI data of October 2018 covering the area of Sakurajima volcano. Yellow/red pixels indicate detected hotspot pixels.

It is worth noting that by analyzing the entire satellite sub-scenes, we found that NHI flagged some hotspot pixels in areas located far from the eruptive center (e.g., see region marked in green on panel of 29 October). These pixels represented artefacts generated by possible cloud-edges effects, which should be taken into account when the algorithm is used.

\subsection{Popocatépetl Eruptive Activity of March 2019}

Figure 10 displays the NHI maps from Sentinel-2 MSI data of March 2019, providing information about thermal activity occurring at Popocatépetl.

Specifically, maps show that a volcanic plume affected most of analyzed satellite scenes. As a result of this issue, NHI partially identified a thermal anomaly within the summit crater in early March (e.g., see panel of $3 \mathrm{March}$ ), while it did not flag any hotspot pixel ascribable to thermal volcanic activity at end of same month (see panel of 28 March). Nevertheless, NHI maps showed the presence of some thermal anomalies in the neighbor non-volcanic areas. We investigated these features using the same approach of Section 5.1. Based on those analyses, we found that thermal anomalies flagged outside the volcano edifice did not represent false positives ascribable to clouds (e.g., Section 5.5) or background pixels (Section 5.1), but were generated by other high temperature sources. In particular, possible fires, occurring both at the slopes (e.g., see pixels within the green box) and in the surrounding of the investigated volcanic area (green circles), generated the thermal anomalies identified and mapped by satellite. 

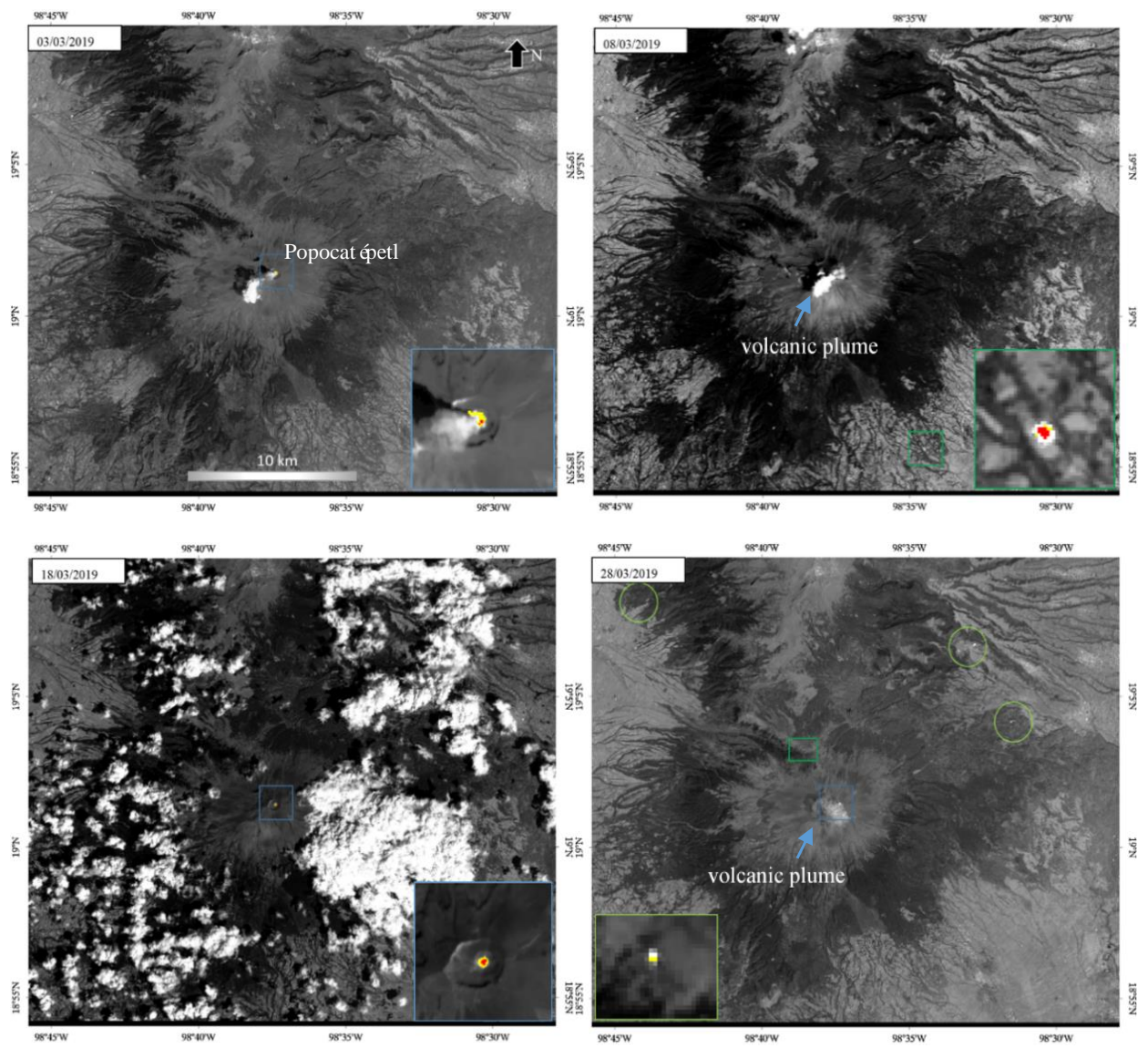

Figure 10. NHI maps from Sentinel-2 MSI data of March 2019 covering the Popocatepetl. Yellow/red pixels, within the region marked in blue, indicated an intra-crater thermal activity. Hotspot pixels within the areas marked in green were possibly associated to fires occurring at the volcano's slopes (green box) and far from the volcano edifice (green circles).

\subsection{Shiveluch Thermal Activity of March 2016-April 2019}

To assess the NHI capacity in mapping volcanic thermal anomalies also at the high latitude regions (i.e., in presence of a cold background), we investigated the Shiveluch thermal activity by means of Landsat 8 OLI data of March 2016-April 2019.

Results of this analysis are shown in Figure 11a, revealing the occurrence of three major events (i.e., 2 March, 2016, 13 September, 2017 and 7 February, 2019) at the target area, and of a number of minor thermal volcanic activities, during the period of interest. Both major and minor events were consistent with information provided by the RGB product, which was generated using bands 7 (Red), 6 (Green), and 5 (Blue) of OLI. Figure 11b displays, for instance, the NHI map from Landsat 8 OLI data of 2 March 2016, showing the good agreement of detected thermal anomaly (see yellow pixels on bottom-left panel) with that emphasized by the false color composite imagery (see yellow/red colored pixels on bottom-right panel). Moreover, although NHI did not detect all the hotspot pixels associated to the eruptive activity in progress on that day probably due to the presence of a volcanic plume, the thermal anomaly in Figure 11a was consistent also with information provided by some well-established satellite-based monitoring systems (see Section 2.7). This agreement characterized also the thermal anomaly shown in Figure $11 \mathrm{~b}$, which was identified by NHI analyzing the Landsat 8 OLI data of 19 April, 2019. In particular, the detected thermal anomaly fits with the frequent and independent observation of volcanic hotspots, mostly located within the summit crater area, during the period January-April 2019 (e.g., [85]). 


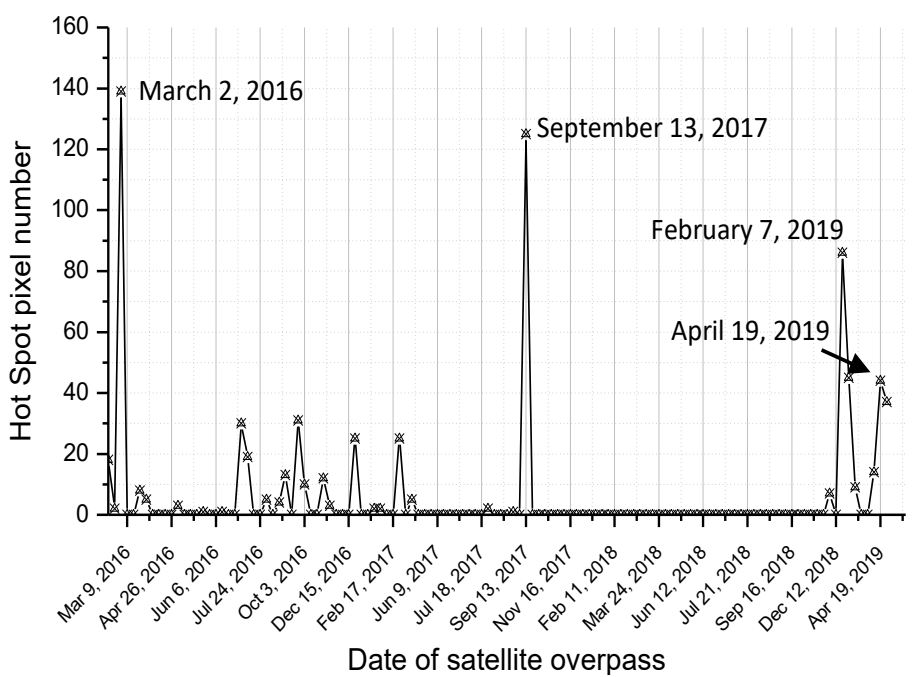

(a)

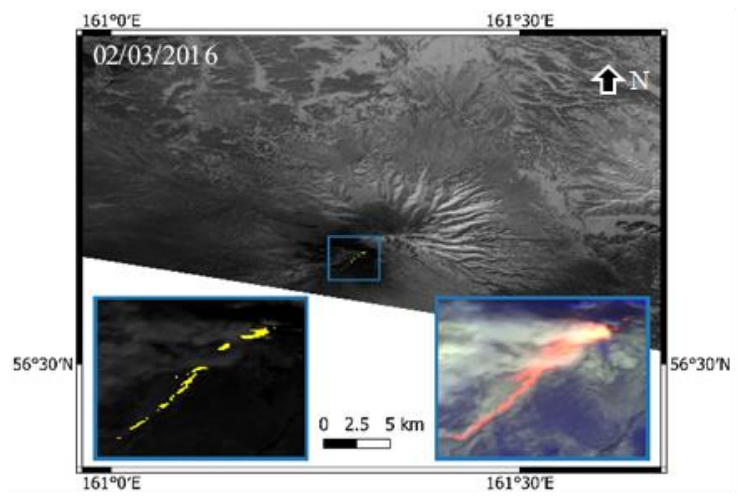

(b)

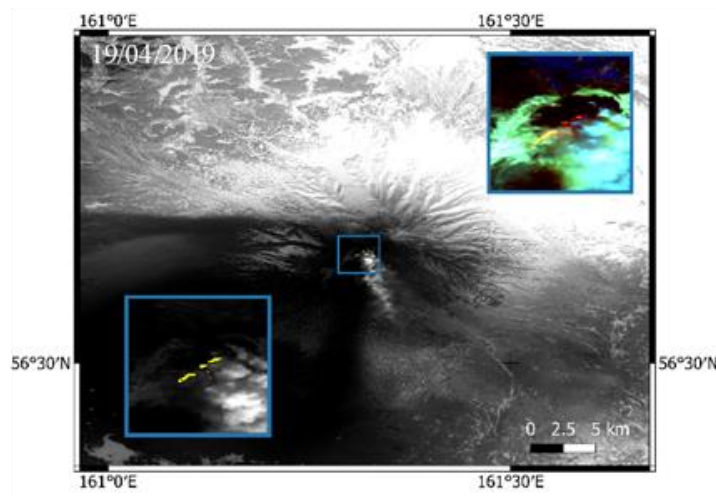

(c)

Figure 11. (a) Temporal trend of hotspot pixels identified by NHI at Shiveluch volcano analyzing Landsat 8 OLI data of March 2016-April 2019; (b) NHI map (B7 imagery is displayed in background) and RGB product (bottom-right panel) from satellite scene of 2 March, 2016; (c) NHI map and RGB product (top-right panel) from satellite scene of 19 April, 2019. The RGB product was generated using band B7 (Red), B6 (Green), and B5 (Blue) of OLI.

\subsection{Piton de la Fournaise Lava Effusions of April 2018-June 2019}

Figure 12 shows two NHI maps including the area of Piton de La Fournaise (Reunion Island), generated from Landsat 8 OLI data.

In detail, Figure 12a displays the NHI map of 12 May, 2018, where the detected thermal anomaly (see red pixels magnified at the bottom-right side of the figure) was consistent with a documented lava effusion began the previous month (see Section 2.8). Figure 12b shows the map of 24 February, 2019 , providing information about the lava flow emitted on the E flank of the volcano. The comparison of those maps with the false color composite imagery corroborated information provided by NHI. Regarding the lava effusion of 11 June, 2019 (see Section 2.8), it was investigated using Sentinel 2 MSI data of that day, since the Landsat 8 OLI scene covering the target area was not available. Figure 12c displays the NHI map revealing the presence of a significant thermal anomaly (for intensity and spatial extent) affecting the SE flank of the volcano, which was mostly consistent with information provided by the RGB product (top-right panel). Main differences were ascribable to a few artefacts generated within the region marked in green (see yellow pixels), and to hotspot pixels undetected by NHI in the inner part of the lava flow (due to possible saturation effects of SWIR channels under investigation). 
This example shows that NHI is a capable of well exploiting advantages of Landsat 8 OLI and Sentinel 2 MSI data integration despite some limitations.

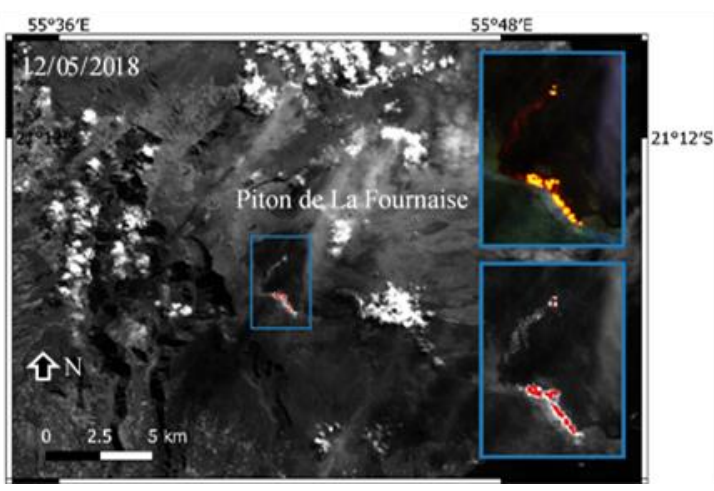

(a)

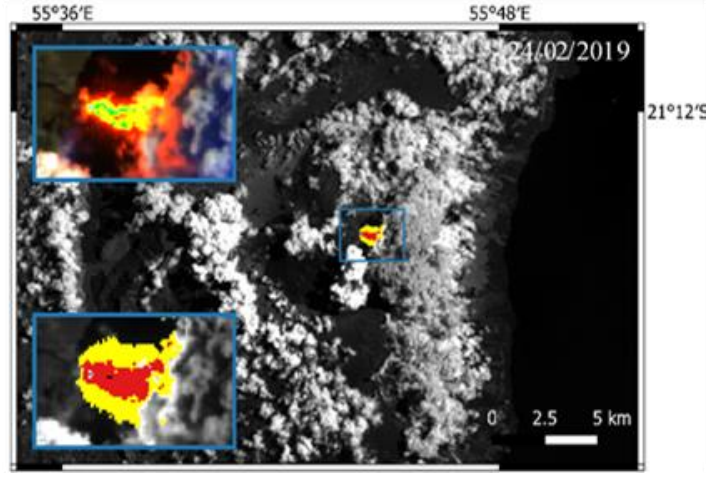

(b)

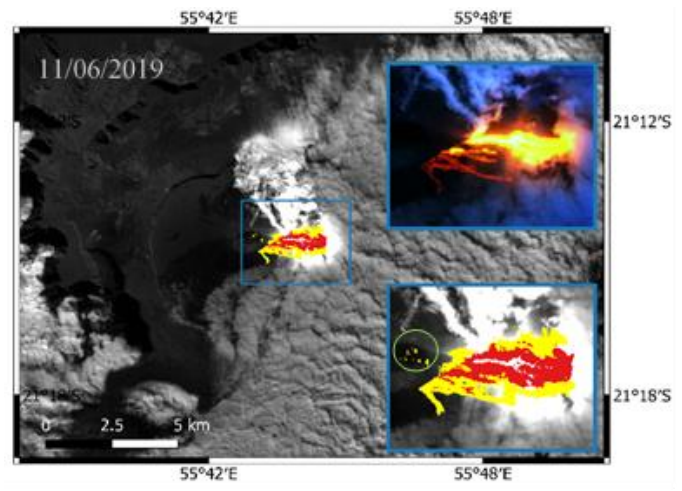

(c)

Figure 12. NHI map of Piton de La Fournaise generated from Landsat 8 OLI data of (a) 12 May, 2018; (b) 24 February, 2019; (c) NHI map from Sentinel 2 MSI data (B12 imagery is displayed in background) of 11 June, 2019. At the top of each panel, the RGB product generated as Figure 11.

\section{Discussion}

By testing the NHI algorithm in the volcanic areas of Figure 1, we found the good agreement of thermal anomalies identified using infrared Sentinel 2 MSI and Landsat 8 OLI data with volcanic activities reported by field reports. Additionally, independent satellite-based observations further corroborated information provided by NHI. In the case of Erta Ale eruptions, volcanic thermal anomalies were for instance consistent with those catalogued and collected by the ASTER Volcano Archive (AVA) system using ASTER data (e.g., see hotspot products in [86] temporally close to NHI maps of Figure 7). Concerning the Mt. Etna activity, NHI detections fitted with results of a recent independent study, performed using Sentinel 2 MSI and EOS-MODIS data [75] and with outputs of the highly sensitive $\mathrm{RST}_{\text {VOLC }}$ algorithm monitoring Italian volcanoes in near-real time (e.g., [87]). Figure 13 displays the temporal trend of hotspot pixels flagged by NHI (Figure 13a) and RST VOLC (Figure 13b) during the period July-February 2019. By looking at the figure, it can be noted as NHI detections were corroborated by the RST VOLC ones (e.g., see thermal anomalies flagged during 25-27 August and 24-27 December, 2018 lava effusion periods). Additionally, although the low temporal sampling of Sentinel 2 MSI data did not enable the same continuity of NOAA/Metop (National Oceanic and Atmospheric Administration/Meteorological Operational Satellites)-AVHRR observations, the $20 \mathrm{~m}$ spatial resolution favored the identification of some minor events (e.g., early July 2018; February 2019). They included modest Strombolian activities generated by vents at the bottom of the summit craters, incandescent gas emissions, and fumaroles from fractures. This analysis confirmed advantages of integrating information 
from different satellite-based systems for better investigating changes of thermal volcanic activity also in well-monitored volcanic areas (e.g., [88]).

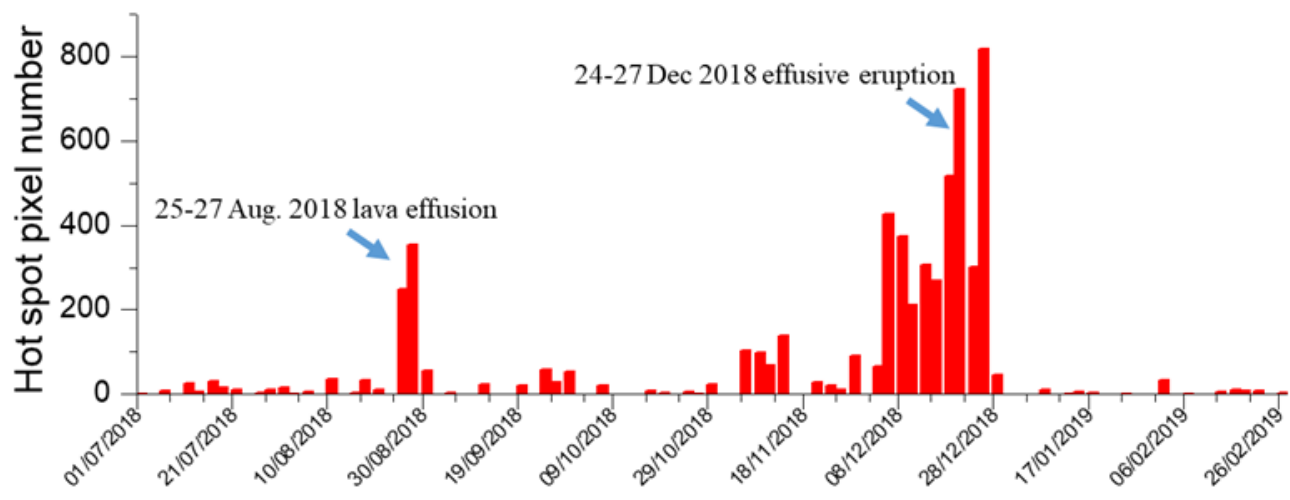

(a)

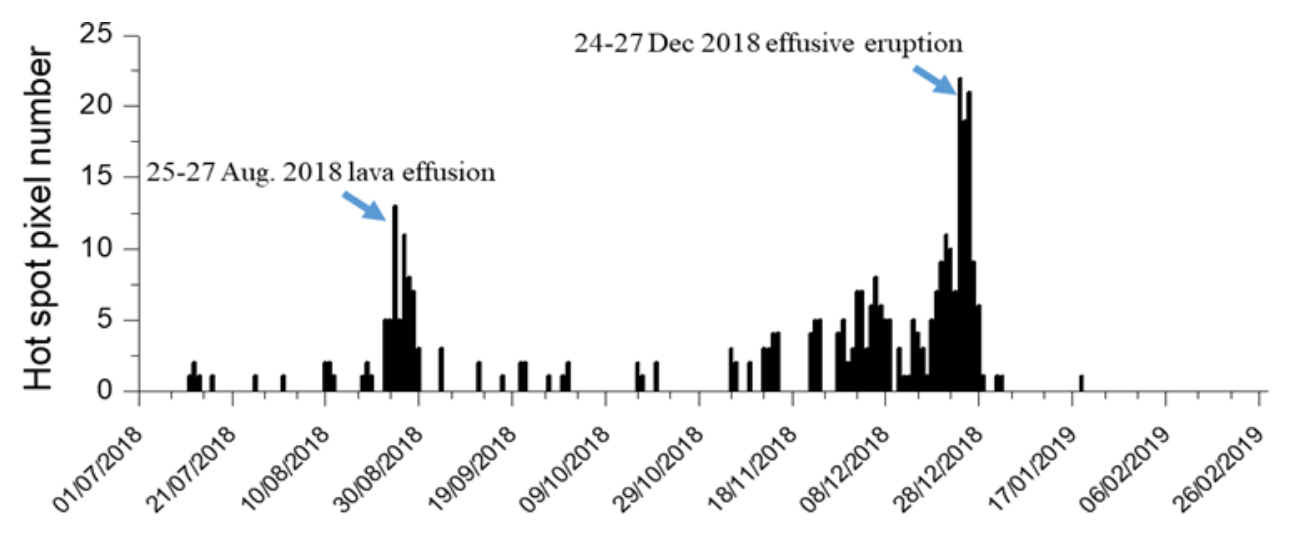

(b)

Figure 13. Hotspot pixels flagged at Mt. Etna during July 2018-February 2019 by: (a) NHI from Sentinel-2 MSI data; (b) RST VOLC from National Oceanic and Atmospheric Administration (NOAA) and Meteorological Operational Satellites (Metop)-Advanced Very High Resolution Radiometer (AVHRR) records, after filtering data for values of satellite zenith angle lower than $40^{\circ}$.

Regarding the factors affecting the NHI performance, clouds had the major impact on results of this study. Indeed, about 38\% of analyzed Sentinel 2 MSI scenes (about 90 in total) were almost completely overcast did not enabling the identification of volcanic thermal anomalies. Additionally, by the manual inspection of satellite imagery, and the comparison with RGB product, we found that NHI underestimated some volcanic thermal anomalies in presence of clouds/volcanic plumes (e.g., see Section 5.6) partially affecting the target areas and leading to negative values of used indices. On the other hand, background pixels showing radiance values slightly higher at $2.2 \mu \mathrm{m}$ than 1.6. $\mu \mathrm{m}$ wavelength generated artefacts associated to positive values of the index in Equation (1) (e.g., see Section 5.1). To minimize this issue, an initial test on SWIR radiance might be used before computing the NHI indices as shown in Figure 14, displaying the thermal anomaly map generated, under Google Earth Engine [89] using the preliminary NHI tool, from Landsat OLI data of 24 February, 2019. It can be noted as artefacts in Figure 12c, i.e., false hotspot pixels within the region marked in green, could be efficiently removed optimizing the algorithm (e.g., filtering pixels with values of $L_{2.2}<3.0 \mathrm{~W} \mathrm{~m}^{-2} \mathrm{sr}^{-1} \mu \mathrm{m}^{-1}$ ). Hence, the confidence level of NHI detections may be further increased; in this direction, we could use also cloud-masking procedure to minimize false positives related to possible cloud-edge effects (see Section 5.5). 


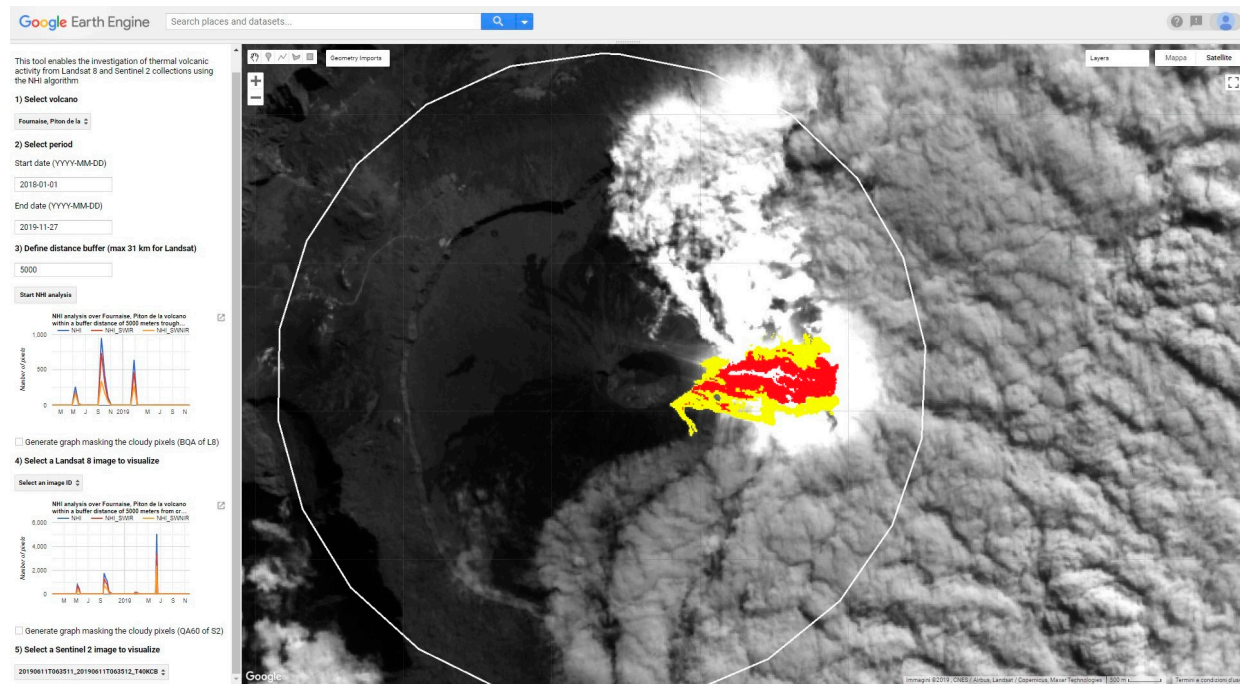

Figure 14. NHI map from Sentinel 2 MSI data of 11 June, 2019, generated after filtering pixels with values of $L_{2.2}<3.0 \mathrm{~W} \mathrm{~m}^{-2} \mathrm{sr}^{-1} \mu \mathrm{m}^{-1}$, showing the lava flow at Piton de la Fournaise (see yellow/red pixels). Elaboration was performed under Google Earth Engine using the preliminary NHI tool.

Since NHI is also sensitive to fires, a spatial distance filter might be integrated within the process to avoid the misinterpretation of detected thermal anomalies at the investigated volcanic areas. Bush fires generally develop along the volcano flanks due to the fallout of incandescent blocks on vegetated areas (e.g., see Section 2.6). Nevertheless, they may also occur because of anthropogenic causes, as for the Vesuvius (Italy) volcanic area on 12 July, 2017. Figure 15 shows the NHI map from Sentinel 2 MSI data of that day, showing the identification of several thermal anomalies on both flanks and slopes of this high-risk volcano, which were generated by a number of well-documented anthropogenic fires burning several hectares of vegetation (e.g., [77]). The use of a spatial filter analyzing distance of detected hotspot pixels from summit craters could then enable a better discrimination of volcanic thermal anomalies from bush fires, especially in remote areas where validation sources usually lack (e.g., [90]). On the other hand, Figure 15 confirms that NHI might potentially be used for mapping thermal anomalies from different sources (e.g., fires; gas flares), although further and more accurate investigations have to be performed to assess this potential, which is out of the scope of this study.

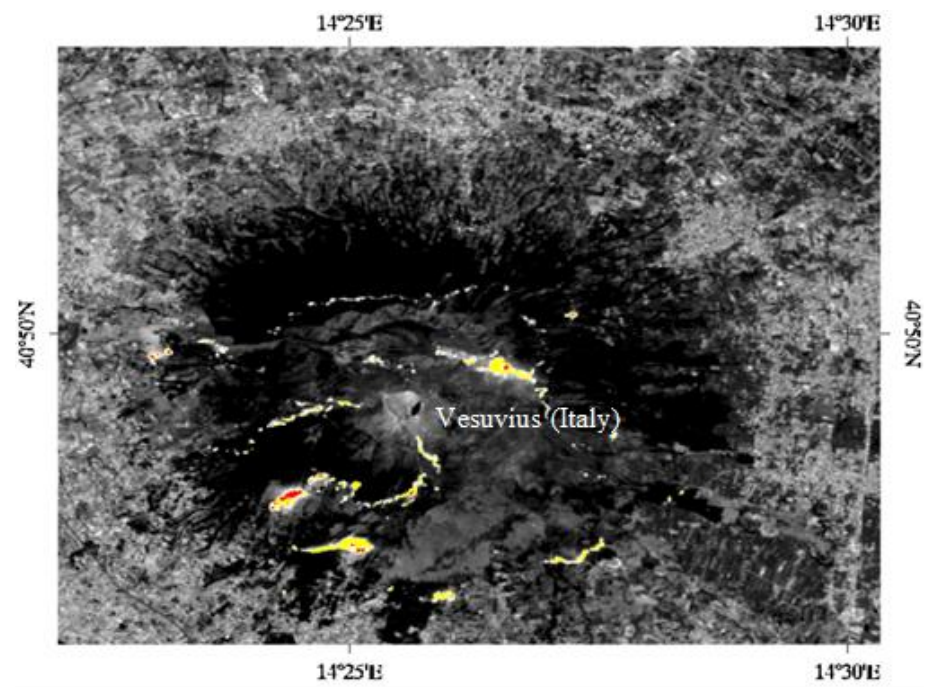

Figure 15. NHI map from Sentinel-2 MSI data of 12 July 2007 at 09:50 UTC showing thermal anomalies (yellow/red pixels) associated to several documented anthropogenic fires affecting flanks and slopes of the Vesuvius volcano (Italy). 
The use of spectral/spatial filters described above should make NHI even more suited for mapping volcanic thermal anomalies at a global scale. In this context, the low processing times and the direct exportability to satellite data from other sensors as the Visible Infrared Imaging Radiometer Suite (VIIRS) represent other important advantages offered by the algorithm proposed and tested in this work.

\section{Conclusions}

In this paper, we have presented a single image multi-channel algorithm for mapping volcanic thermal anomalies at a global scale using Sentinel 2 MSI and Landsat 8 OLI data.

Results revealed the NHI potential in mapping both weak (e.g., fumarole fields) and more intense (e.g., lava bodies) volcanic thermal anomalies in spite of some limitations. Moreover, by combining two normalized indices, NHI provided qualitative information about intensity of detected thermal anomalies, in both remote (e.g., Erta Ale) and well-monitored (e.g., Mt. Etna; Stromboli) volcanic areas.

The use of additional spectral/spatial tests should further increase the NHI performance, enabling a more efficient identification of hot volcanic targets in daylight conditions. In this direction, once a sufficiently populated dataset of Sentinel 2 MSI/Landsat 8 OLI scenes will be available, the implementation of NHI within a well-established multi-temporal scheme of satellite data analysis (e.g., [91]) will be evaluated to increase the accuracy of detection, avoiding the use fixed threshold tests which are intrinsically affected by known limitations.

A NHI-based tool, which benefits from the computation capabilities of Google Earth Engine, a cloud-based platform for planetary-scale environmental data analysis whose catalog is continuously updated with a latency of about $24 \mathrm{~h}$ from data acquisition time (e.g., [92], is under development. The tool will enable a quick visualization of thermal anomalies flagged by NHI at volcanoes and periods of interest (e.g., see Figure 14), supporting end-users (e.g., volcano observatories) in retrieving information about location, shape, and spatial extent of volcanic thermal anomalies.

Finally, the low processing times make NHI (which could be potentially used for investigating hot targets from different sources) suited for operational contexts, by exploiting the increased revisit time of the combined Landsat 8 and Sentinel-2A/2B satellites. This way, NHI could complement observations from current satellite-based monitoring systems (e.g., those analyzing high temporal resolution satellite data), contributing to the surveillance of active volcanoes from space.

Author Contributions: Conceptualization, N.P., F.M.; methodology F.M.; writing-original draft preparation F.M.; validation, F.M., M.N., N.G., G.M.; software, N.G.; formal analysis, F.M., G.M., and A.F.; resources, N.P.

Funding: The study did not receive any funding.

Acknowledgments: Sentinel-2 MSI and Landsat 8 OLI data used in this work were made freely available online by Copernicus Open Access Hub and USGS (U.S. Geological Survey) respectively, through the Google Earth Engine platform.

Conflicts of Interest: The authors declare no conflict of interest.

\section{References}

1. Gawarecki, S.J.; Lyon, R.J.P.; Nordberg, W. Infrared spectral returns and imagery of the Earth from space and their application to geological problems. Sci. Technol. Ser. Am. Astron. Soc. 1965, 4, 13-33.

2. Williams, R.S., Jr.; Friedman, J.D. Satellite observation of effusive volcanism. Br. Interplanet. Soc. J. 1970, 23, 441-450.

3. Fiske, R.S.; Sigurdsson, H. Soufriere Volcano, St. Vincent: Observations of its 1979 eruption from the ground, aircraft, and satellites. Science 1982, 216, 1105-1106. [CrossRef] [PubMed]

4. Oppenheimer, C. Lava flow cooling estimated from Landsat Thematic Mapper infrared data: The Lonquimay eruption (Chile, 1989). J. Geophys. Res. Solid Earth 1991, 96, 21865-21878. [CrossRef]

5. Rothery, D.A.; Francis, P.W.; Wood, C.A. Volcano monitoring using short wavelength infrared data from satellites. J. Geophys. Res. Solid Earth 1998, 93, 7993-8008. [CrossRef]

6. Dean, K.; Servilla, M.; Roach, A.; Foster, B.; Engle, K. Satellite monitoring of remote volcanoes improves study efforts in Alaska. EosTrans. Am. Geophys. Union 1998, 79, 413-423. [CrossRef] 
7. Dehn, J.; Dean, K.; Engle, K. Thermal monitoring of North Pacific volcanoes from space. Geology 2000, 28, 755-758. [CrossRef]

8. Wright, R.; Carn, S.A.; Flynn, L.P. A satellite chronology of the May-June 2003 eruption of Anatahan volcano. J. Volcanol. Geotherm. Res. 2005, 146, 102-116. [CrossRef]

9. Coppola, D.; Cigolini, C. Thermal regimes and effusive trends at Nyamuragira volcano (DRC) from MODIS infrared data. Bull. Volcanol. 2013, 75, 744. [CrossRef]

10. Higgins, J.; Harris, A. VAST: A program to locate and analyze volcanic thermal anomalies automatically from remotely sensed data. Comput. Geosci. 1997, 23, 627-645. [CrossRef]

11. Harris, A.J.; Butterworth, A.L.; Carlton, R.W.; Downey, I.; Miller, P.; Navarro, P.; Rothery, D.A. Low-cost volcano surveillance from space: Case studies from Etna, Krafla, Cerro Negro, Fogo, Lascar and Erebus. Bull. Volcanol. 1997, 59, 49-64. [CrossRef]

12. Pergola, N.; Marchese, F.; Tramutoli, V. Automated detection of thermal features of active volcanoes by means of infrared AVHRR records. Remote Sens. Environ. 2004, 93, 311-327. [CrossRef]

13. Wright, R.; Pilger, E. Radiant flux from Earth's subaerially erupting volcanoes. Int. J. Remote Sens. 2008, 29, 6443-6466. [CrossRef]

14. Lombardo, V. AVHotRR: Near-real time routine for volcano monitoring using IR satellite data. Geol. Soc. Lond. Spec. Publ. 2016, 426, 73. [CrossRef]

15. Vicari, A.; Ganci, G.; Behncke, B.; Cappello, A.; Neri, M.; Del Negro, C. Near-real-time forecasting of lava flow hazards during the 12-13 January 2011 Etna eruption. Geophys. Res. Lett. 2011, 38, 47545. [CrossRef]

16. Wright, R.; Flynn, L.P.; Garbeil, H.; Harris, A.J.; Pilger, E. MODVOLC: Near-real-time thermal monitoring of global volcanism. J. Volcanol. Geotherm. Res. 2004, 135, 29-49. [CrossRef]

17. Coppola, D.; Laiolo, M.; Cigolini, C.; Delle Donne, D.; Ripepe, M. Enhanced volcanic hot-spot detection using MODIS IR data: Results from the MIROVA system. Geol. Soc. Lond. Spec. Publ. 2016, 426, 181-205. [CrossRef]

18. Marchese, F.; Filizzola, C.; Genzano, N.; Mazzeo, G.; Pergola, N.; Tramutoli, V. Assessment and improvement of a Robust Satellite Technique (RST) for thermal monitoring of volcanoes. Remote Sens. Environ. 2011, 115, 1556-1563. [CrossRef]

19. Harris, A.J.L.; Pilger, E.; Flynn, L.P.; Garbeil, H.; Mouginis-Mark, P.J.; Kauahikaua, J.; Thornber, C. Automated, high temporal resolution, thermal analysis of Kilauea volcano, Hawai'i, using GOES satellite data. Int. J. Remote Sens. 2001, 22, 945-967. [CrossRef]

20. Pergola, N.; Marchese, F.; Tramutoli, V.; Filizzola, C.; Ciampa, M. Advanced satellite technique for volcanic activity monitoring and early warning. Ann. Geophys. 2008, 51, 287-301.

21. Ferrucci, F.; Theys, N.; Hirn, B.; Clarisse, L.; Valks, P.; Laneve, G.; van der A, R.; Tait, S.; Brenot, H. Operational integration of spaceborne measurements of lava discharge rates and sulfur dioxide concentrations for global volcano monitoring. In Early Warning for Geological Disasters; Springer: Berlin/Heidelberg, Germany, 2014; pp. 307-331.

22. Marchese, F.; Falconieri, A.; Pergola, N.; Tramutoli, V. A retrospective analysis of the Shinmoedake (Japan) eruption of 26-27 January 2011 by means of Japanese geostationary satellite data. J. Volcanol. Geotherm. Res. 2014, 269, 1-13. [CrossRef]

23. Kaneko, T.; Takasaki, K.; Maeno, F.; Wooster, M.J.; Yasuda, A. Himawari-8 infrared observations of the June-August 2015 Mt Raung eruption, Indonesia. Earth Planets Space 2018, 70, 1-9. [CrossRef]

24. Pieri, D.; Abrams, M. ASTER observations of thermal anomalies preceding the April 2003 eruption of Chikurachki volcano, Kurile Islands, Russia. Remote Sens. Environ. 2005, 99, 84-94. [CrossRef]

25. Pieri, D.; Abrams, M. ASTER watches the world's volcanoes: A new paradigm for volcanological observations from orbit. J. Volcanol. Geotherm. Res. 2004, 135, 13-28. [CrossRef]

26. Vaughan, R.G.; Hook, S.J. Using satellite data to characterize the temporal thermal behavior of an active volcano: Mount St. Helens, WA. Geophys. Res. Lett. 2006, 33, 1-4. [CrossRef]

27. Reath, K.; Pritchard, M.; Poland, M.; Delgado, F.; Carn, S.; Coppola, D.; Baker, S.; Andrews, B.; Ebmeier, S.K.; Rumpf, E.; et al. Thermal, Deformation, and Degassing Remote Sensing Time Series (CE 2000-2017) at the 47 most Active Volcanoes in Latin America: Implications for Volcanic Systems. J. Geophys. Res. Solid Earth 2019, 124, 195-2018. [CrossRef]

28. Davies, A.G.; Chien, S.; Baker, V.; Doggett, T.; Dohm, J.; Greeley, R.; Ip, C.R.; Cichy, B.; Rabideau, G.; Tran, D.; et al. Monitoring active volcanism with the autonomous sciencecraft experiment on EO-1. Remote Sens. Environ. 2006, 101, 427-446. [CrossRef] 
29. Li, J.; Roy, D.P. A Global Analysis of Sentinel-2A, Sentinel-2B and Landsat-8 Data Revisit Intervals and Implications for Terrestrial Monitoring. Remote Sens. 2017, 9, 902.

30. Murphy, S.W.; de Souza Filho, C.R.; Wright, R.; Sabatino, G.; Pabon, R.C. HOTMAP: Global hot target detection at moderate spatial resolution. Remote Sens. Environ. 2016, 177, 78-88. [CrossRef]

31. Mia, M.; Fujimitsu, Y.; Nishijima, J. Thermal activity monitoring of an active volcano using Landsat 8/OLI-TIRS sensor images: A case study at the Aso volcanic area in southwest Japan. Geosciences 2017, 7, 118. [CrossRef]

32. Mia, M.; Fujimitsu, Y.; Nishijima, J. Monitoring of Thermal Activity at the Hatchobaru-Otake Geothermal Area in Japan Using Multi-Source Satellite Images-With Comparisons of Methods, and Solar and Seasonal Effects. Remote Sens. 2018, 10, 1430. [CrossRef]

33. Cigolini, C.; Coppola, D.; Yokoo, A.; Laiolo, M. The thermal signature of Aso Volcano during unrest episodes detected from space and ground-based measurements. Earth Planets Space 2018, 70, 1-15. [CrossRef]

34. Valade, S.; Ley, A.; Massimetti, F.; D’Hondt, O.; Laiolo, M.; Coppola, D.; Loibl, D.; Hellwich, O.; Walter, T.R. Towards Global Volcano Monitoring Using Multisensor Sentinel Missions and Artificial Intelligence: The MOUNTS Monitoring System. Remote Sens. 2019, 11, 1528. [CrossRef]

35. Marchese, F.; Neri, M.; Falconieri, A.; Lacava, T.; Mazzeo, G.; Pergola, N.; Tramutoli, V. The Contribution of Multi-Sensor Infrared Satellite Observations to Monitor Mt. Etna (Italy) Activity during May to August 2016. Remote Sens. 2018, 10, 1948. [CrossRef]

36. Gray, D.M.; Burton-Johnson, A.; Fretwell, P.T. Evidence for a lava lake on Mt. Michael volcano, Saunders Island (South Sandwich Islands) from Landsat, Sentinel-2 and ASTER satellite imagery. J. Volcanol. Geotherm. Res. 2019, 379, 60-71. [CrossRef]

37. Xia, H.; Chen, Y.; Quan, J. A simple method based on the thermal anomaly index to detect industrial heat sources. Int. J. Appl. Earth Obs. Geoinf. 2018, 73, 627-637. [CrossRef]

38. Neri, M.; Acocella, V.; Behncke, B.; Giammanco, S.; Mazzarini, F.; Rust, D. Structural analysis of the eruptive fissures at Mount Etna (Italy). Ann. Geophys. 2011, 54. [CrossRef]

39. Global Volcanism Program. Report on Etna (Italy). In Bulletin of the Global Volcanism Network; Crafford, A.E., Venzke, E., Eds.; Smithsonian Institution: Washington, DC, USA, 2018; Volume 43. [CrossRef]

40. De Novellis, V.; Atzori, S.; De Luca, C.; Manzo, M.; Valerio, E.; Bonano, M.; Cardaci, C.; Castaldo, L.; Di Bucci, D.; Manunta, M.; et al. DInSAR analysis and analytical modeling of Mount Etna displacements: The December 2018 volcano-tectonic crisis. Geophys. Res. Lett. 2019, 46. [CrossRef]

41. Global Volcanism Program. Report on Etna (Italy). In Bulletin of the Global Volcanism Network; Crafford, A.E., Venzke, E., Eds.; Smithsonian Institution: Washington, DC, USA, 2019; Volume 44.

42. Ripepe, M.; Delle Donne, D.; Lacanna, G.; Marchetti, E.; Ulivieri, G. The onset of the 2007 Stromboli effusive eruption recorded by an integrated geophysical network. J. Volcanol. Geotherm. Res. 2009, 182, 131-136. [CrossRef]

43. Calvari, S.; Spampinato, L.; Lodato, L.; Harris, A.J.; Patrick, M.R.; Dehn, J.; Burton, M.R.; Andronico, D. Chronology and complex volcanic processes during the 2002-2003 flank eruption at Stromboli volcano (Italy) reconstructed from direct observations and surveys with a handheld thermal camera. J. Geophys. Res. Solid Earth 2005, 110, 3129. [CrossRef]

44. Calvari, S.; Bonaccorso, A.; Madonia, P.; Neri, M.; Liuzzo, M.; Salerno, G.; Behncke, B.; Caltabiano, T.; Cristaldi, A.; Giuffrida, G.; et al. Major eruptive style changes induced by structural modifications of a shallow conduit system: The 2007-2012 Stromboli case. Bull. Volcanol. 2014, 76, 841. [CrossRef]

45. Global Volcanism Program. Report on Stromboli (Italy). In Bulletin of the Global Volcanism Network; Venzke, E., Ed.; Smithsonian Institution: Washington, DC, USA, 2018; Volume 43, p. 8.

46. Volcano Discovery. The Explosion of Stromboli on 3 July 2019-A Summary. Available online: https: //www.volcanodiscovery.com/stromboli/eruptions/3july2019-explosion.html (accessed on 19 November 2019).

47. Volcano Discovery. Erta Ale. Available online: https://www.volcanodiscovery.com/it/erta_ale.html (accessed on 19 November 2019).

48. Global Volcanism Program. Report on Erta Ale (Ethiopia). In Bulletin of the Global Volcanism Network; Venzke, E., Ed.; Smithsonian Institution: Washington, DC, USA, 2017; Volume 42, p. 7.

49. Volcano Discovery. Erta Ale, 2017 Rift Eruption-June Update. Available online: https://www.volcanodiscovery. com/erta-ale/news/2017-rift-eruption/june-update.html\#top (accessed on 19 November 2019).

50. Conway, S.; Wauthier, C.; Fukushima, Y.; Poland, M. A retrospective look at the February 1993 east rift zone intrusion at Kīlauea volcano, Hawaii. J. Volcanol. Geotherm. Res. 2018, 358, 241-251. [CrossRef] 
51. Global Volcanism Program. Report on Kilauea (United States). In Bulletin of the Global Volcanism Network; Venzke, E., Ed.; Smithsonian Institution: Washington, DC, USA, 2018; Volume 43, p. 12.

52. Neal, C.A.; Brantley, S.R.; Antolik, L.; Babb, J.L.; Burgess, M.; Calles, K.; Chang, J.C.; Conway, S.; Desmither, L.; Dotray, P.; et al. The 2018 rift eruption and summit collapse of Kīlauea Volcano. Science 2018, 363, 367-374. [CrossRef] [PubMed]

53. Global Volcanism Program. Report on Aira (Japan). In Bulletin of the Global Volcanism Network; Krippner, J.B., Venzke, E., Eds.; Smithsonian Institution: Washington, DC, USA, 2019; Volume 44, p. 1.

54. Global Volcanism Program. Report on Popocatepetl (Mexico). In Bulletin of the Global Volcanism Network; Venzke, E., Ed.; Smithsonian Institution: Washington, DC, USA, 2018; Volume 43, p. 11.

55. GARDAWORLD. Mexico: Increased Volcanic Activity Reported at Popocatepetl March 28/Update 1. Available online: https://www.garda.com/crisis24/news-alerts/209421/mexico-popocatepetl-volcano-expels-vaporsand-ashes-march-3 (accessed on 19 November 2019).

56. Global Volcanism Program. Report on Popocatepetl (Mexico). In Weekly Volcanic Activity Report; Sennert, S.K., Ed.; Smithsonian Institution: Washington, DC, USA; US Geological Survey: Reston, VA, USA, 2019.

57. Volcano Discovery. Popocatepetl Volcano News \& Eruption Update. Available online: https://www.volcanodiscovery.com/popocatepetl/news/77782/Popocatepetl-Volcano-Volcanic-AshAdvisory-REMNANT-VA-to-21000-ft-6400-m.html (accessed on 19 November 2019).

58. Ramsey, M.S.; Wessels, R.L.; Anderson, S.W. Surface textures and dynamics of the 2005 lava dome at Shiveluch Volcano, Kamchatka. Bulletin 2012, 124, 678-689. [CrossRef]

59. Kamchatka Volcanic Eruption Response Team (KVERT). Available online: http://www.kscnet.ru/ivs/kvert/ about_eng (accessed on 19 November 2019).

60. Global Volcanism Program. Report on Sheveluch (Russia). In Bulletin of the Global Volcanism Network; Venzke, E., Ed.; Smithsonian Institution: Washington, DC, USA, 2017; Volume 42, p. 8. [CrossRef]

61. Middle InfraRed Observation of Volcanic Activity (MIROVA). Near Real Time Volcanic Hotspot Detection System. Available online: http://www.mirovaweb.it/ (accessed on 19 November 2019).

62. Global Volcanism Program. Report on Sheveluch (Russia). In Bulletin of the Global Volcanism Network; Venzke, E., Ed.; Smithsonian Institution: Washington, DC, USA, 2019; Volume 44, p. 5.

63. Volcano Discovery. Piton de la Fournaise Vulcano. Available online: https:/www.volcanodiscovery.com/it/ pitondelafournaise.html (accessed on 19 November 2019).

64. Global Volcanism Program. Report on Piton de la Fournaise (France). In Bulletin of the Global Volcanism Network; Crafford, A.E., Venzke, E., Eds.; Smithsonian Institution: Washington, DC, USA, 2019; Volume 44, p. 7.

65. Global Volcanism Program. Report on Piton de la Fournaise (France). In Weekly Volcanic Activity Report; Sennert, S.K., Ed.; Smithsonian Institution: Washington, DC, USA; US Geological Survey: Reston, VA, USA, 2018.

66. Martimort, P.; Fernandez, V.; Kirschner, V.; Isola, C.; Meygret, A. Sentinel-2 MultiSpectral imager (MSI) and calibration/validation. In Proceedings of the 2012 IEEE International Geoscience and Remote Sensing Symposium, Munich, Germany, 22-27 July 2007; pp. 6999-7002.

67. ESA Sentinel Online. Missions, SENTINEL 2. Available online: https://sentinel.esa.int/web/sentinel/missions/ sentinel-2 (accessed on 19 November 2019).

68. ESA Sentinel Online. SWAT and Resolution. Available online: https://sentinel.esa.int/web/sentinel/missions/ sentinel-2/instrument-payload/resolution-and-swath (accessed on 19 November 2019).

69. Copernicus Open Access Hub. Available online: https://scihub.copernicus.eu/dhus/\#/home (accessed on 19 November 2019).

70. ESA Sentinel Online. User Guides. Level-1C. Available online: https://earth.esa.int/web/sentinel/user-guides/ sentinel-2-msi/product-types/level-1c (accessed on 19 November 2019).

71. ESA Copernicus. S2 MPC- L1C Data Quality. Available online: https://sentinel.esa.int/documents/247904/ 685211/Sentinel-2_L1C_Data_Quality_Report (accessed on 19 November 2019).

72. U.S. Geological Survey (USGS). Landsat Mission. Available online: https://www.usgs.gov/land-resources/ nli/landsat/landsat-satellite-missions?qt-science_support_page_related_con=2\#qt-science_support_page_ related_con (accessed on 19 November 2019).

73. Markham, B.; Barsi, J.; Kvaran, G.; Ong, L.; Kaita, E.; Biggar, S.; Czapla-Myers, J.; Mishra, N.; Helder, D. Landsat-8 Operational Land Imager Radiometric Calibration and Stability. Remote Sens. 2014, 6, 12275-12308. [CrossRef] 
74. Giglio, L.; Csiszar, I.; Restás, Á.; Morisette, J.T.; Schroeder, W.; Morton, D.; Justice, C.O. Active fire detection and characterization with the advanced spaceborne thermal emission and reflection radiometer (ASTER). Remote Sens. Environ. 2008, 112, 3055-3063. [CrossRef]

75. Laiolo, M.; Ripepe, M.; Cigolini, C.; Coppola, D.; Della Schiava, M.; Genco, R.; Innocenti, L.; Lacanna, G.; Marchetti, E.; Massimetti, F.; et al. Space- and Ground-Based Geophysical Data Tracking of Magma Migration in Shallow Feeding System of Mount Etna Volcano. Remote Sens. 2019, 11, 1182. [CrossRef]

76. Schroeder, W.; Oliva, P.; Giglio, L.; Quayle, B.; Lorenz, E.; Morelli, F. Active fire detection using Landsat-8/OLI data. Remote Sens. Environ. 2016, 185, 210-220. [CrossRef]

77. Cicala, L.; Angelino, C.V.; Fiscante, N.; Ullo, S.L. Landsat-8 and Sentinel-2 for fire monitoring at a local scale: A case study on Vesuvius. In Proceedings of the 2018 IEEE International Conference on Environmental Engineering, Milan, Italy, 12-14 March 2018; pp. 1-6.

78. Donegan, S.J.; Flynn, L.P. Comparison of the response of the Landsat 7 Enhanced Thematic Mapper Plus and the Earth Observing-1 Advanced Land Imager over active lava flows. J. Volcanol. Geotherm. Res. 2004, 135, 105-126. [CrossRef]

79. Carter, A.J.; Girina, O.; Ramsey, M.S.; Demyanchuk, Y.V. ASTER and field observations of the 24 December 2006 eruption of Bezymianny Volcano, Russia. Remote Sens. Environ. 2008, 112, 2569-2577. [CrossRef]

80. Wooster, M.J.; Rothery, D.A. Thermal monitoring of Lascar Volcano, Chile, using infrared data from the along-track scanning radiometer: A 1992-1995 time series. Bull. Volcanol. 1997, 58, 566-579. [CrossRef]

81. Blackett, M. Early analysis of Landsat- 8 thermal infrared sensor imagery of volcanic activity. Remote Sens. 2014, 6, 2282-2295. [CrossRef]

82. Dennison, P.E.; Roberts, D.A. Daytime fire detection using airborne hyperspectral data. Remote Sens. Environ. 2009, 113, 1646-1657. [CrossRef]

83. Escuin, S.; Navarro, R.; Fernandez, P. Fire severity assessment by using NBR (Normalized Burn Ratio) and NDVI (Normalized Difference Vegetation Index) derived from LANDSAT TM/ETM images. Int. J. Remote Sens. 2008, 29, 1053-1073. [CrossRef]

84. Global Volcanism Program. Report on Stromboli (Italy). In Weekly Volcanic Activity Report; Sennert, S.K., Ed.; Smithsonian Institution: Washington, DC, USA; US Geological Survey: Reston, VA, USA, 2019.

85. KVERT Information Releases. Sheveluch Volcano. Available online: http://www.kscnet.ru/ivs/kvert/van/ index.php?type=2\&name=Sheveluch (accessed on 19 November 2019).

86. ASTER Volcano Archive (AVA). Available online: https://ava.jpl.nasa.gov/about.php (accessed on 19 November 2019).

87. Pergola, N.; Coviello, I.; Filizzola, C.; Lacava, T.; Marchese, F.; Paciello, R.; Tramutoli, V. A review of RSTVOLC, an original algorithm for automatic detection and near-real-time monitoring of volcanic hotspots from space. Geol. Soc. Lond. Spec. Publ. 2016, 426, 55-72. [CrossRef]

88. Plank, S.; Marchese, F.; Filizzola, C.; Pergola, N.; Neri, M.; Nolde, M.; Martinis, S. The July/August 2019 lava flows at the Sciara del Fuoco, Stromboli Analysis from multi-sensor infrared satellite imagery. Remote Sens. 2019, in press.

89. Google Earth Engine, a Planetary-Scale Platform for Earth Science \& Data Analysis. Available online: https://earthengine.google.com/ (accessed on 19 November 2019).

90. Lacava, T.; Kervyn, M.; Liuzzi, M.; Marchese, F.; Pergola, N.; Tramutoli, V. Assessing performance of the RSTVOLC multi-temporal algorithm in detecting subtle hotspots at Oldoinyo Lengai (Tanzania, Africa) for comparison with MODLEN. Remote Sens. 2018, 10, 1177. [CrossRef]

91. Tramutoli, V. Robust Satellite Techniques (RST) for Natural and Environmental Hazards Monitoring and Mitigation: Theory and Applications. In Proceedings of the 2007 International Workshop on the Analysis of Multi-temporal Remote Sensing Images, Leuven, Belgium, 18-20 July 2007.

92. Gorelick, N.; Hancher, M.; Dixon, M.; Ilyushchenko, S.; Thau, D.; Moore, R. Google Earth Engine: Planetary-scale geospatial analysis for everyone. Remote Sens. Environ. 2017, 202, 18-27. [CrossRef]

(C) 2019 by the authors. Licensee MDPI, Basel, Switzerland. This article is an open access article distributed under the terms and conditions of the Creative Commons Attribution (CC BY) license (http://creativecommons.org/licenses/by/4.0/). 